\title{
Recent advances in the genetics of systemic lupus erythematosus
}

\author{
Donna L Thibault Flesher ${ }^{1}$, Xin Sun ${ }^{1}$, Timothy W Behrens ${ }^{1}$, Robert R Graham ${ }^{1}$, and Lindsey \\ A Criswell $2, \dagger$ \\ ${ }^{1}$ ITGR Human Genetics, Genentech Research \& Early Development, 1 DNA Way, South San \\ Francisco, CA 94080-94990, USA \\ 2 University of California San Francisco, Division of Rheumatology, 374 Parnassus Avenue, San \\ Francisco, CA 94143, USA
}

\begin{abstract}
Systemic lupus erythematosus (SLE) is a systemic autoimmune disease characterized by the production of antinuclear autoantibodies and the inflammatory infiltration of many organ systems. SLE is a complex disorder in which multiple genetic variants, together with environmental and hormonal factors, contribute to disease risk. In this article, we summarize our current understanding of the genetic contribution to SLE in light of recent genome-wide association studies, which have brought the total number of confirmed SLE susceptibility loci to 29. In the second section, we explore the functional implications of these risk loci and, in particular, highlight the role that many of these genes play in the Toll-like receptor and type I interferon signaling pathways. Finally, we discuss the genetic overlap between SLE and other autoimmune and inflammatory conditions as several risk loci are shared among multiple disorders, suggesting common underlying pathogenic mechanisms.
\end{abstract}

\section{Keywords}

genome-wide association studies; pathogenesis; systemic lupus erythematosus; Toll-like receptor signaling; type I interferon signaling

\begin{abstract}
Systemic lupus erythematosus (SLE) is a chronic systemic autoimmune disease that predominantly affects women of childbearing age. The incidence of SLE in the general US population is approximately one in 2000 , with a nine-to-one female gender bias and a two-tofourfold greater prevalence in non-Caucasian compared with Caucasian populations [1]. In SLE, the tissue deposition of autoantibodies and immune complexes (ICs) leads to destructive inflammation in many organ systems, including the skin, blood elements, joints, kidneys, serosa, CNS and other tissues. The clinical manifestations of SLE are diverse, with renal inflammation (glomerulonephritis) being the most common cause of morbidity and mortality. A hallmark of SLE is the production of autoantibodies directed against intracellular antigens, many of which are associated with the nucleic acids DNA or RNA [2]. The cellular and
\end{abstract}

\footnotetext{
${ }^{\dagger}$ Author for correspondence: Tel.: +1 415476 9026, Fax: +1 415476 9370, lindsey.criswell@ucsf.edu. For reprint orders, please contact reprints@expert-reviews.com

Financial \& competing interests disclosure

Donna L Thibault Flesher, Xin Sun, Robert R Graham and Timothy W Behrens are full-time employees of Genentech, Inc. Lindsey A Criswell is supported by NIH grants R01 AR052300, R01 AR22804, P60 AR053308, K24 AR02175 and M01 RR-00079, and has also received support from a Kirkland Scholar Award and the Alliance for Lupus Research. The authors have no other relevant affiliations or financial involvement with any organization or entity with a financial interest in or financial conflict with the subject matter or materials discussed in the manuscript apart from those disclosed.

No writing assistance was utilized in the production of this manuscript.
} 
molecular mechanisms governing inflammation in SLE remain uncertain; however, genetic, environmental and hormonal factors are all hypothesized to play a role.

Systemic lupus erythematosus has a significant genetic component, as familial aggregation studies have shown that siblings of SLE patients have a greater relative risk for the disease compared with the population as a whole. The sibling risk ratio $\left(\lambda_{\mathrm{s}}\right)$ has been estimated to be as high as 29 [3], and monozygotic twin pairs display a higher rate of concordance (34\%) compared with dizygotic twin pairs (3\%) [4,5]. Rare genetic mutations that cause SLE in a Mendelian fashion account for a small fraction of SLE cases; however, examples such as mutations that result in complete deficiencies of complement components provide insight into the critical pathways involved in SLE [6]. In particular, deficiencies in many of the early components of the classical complement pathway are associated with SLE (reviewed in [7]). In total, 41 cases of homozygous $\mathrm{C} 1 \mathrm{q}$ deficiency have been reported and are associated with lupus in over $90 \%$ of known cases [8]. An absence of the $C 2$ gene is relatively common in European populations, with an allele frequency of $1 \%$. Approximately $33 \%$ of patients who are homozygous for this gene deletion develop SLE, and $C 2$ deficiency is associated with autoantibodies against Ro [9]. Deficiency of any of the four alleles of the two $C 4$ genes, $C 4 A$ and $C 4 B$, is associated with SLE, and the rare complete absence of both genes is associated with the highest risk of disease [10]. The genes for the complement components $C 2$ and $C 4$ are in linkage disequilibrium with the major histocompatibility complex (MHC). $C 4 A$ deficiency is linked to the $H L A-B 8-D R 3$ haplotype; however, it is hypothesized that the two polymorphisms contribute independently to the risk of SLE [11].

The majority of SLE cases involve a complex pattern of inheritance, where multiple genes and environmental triggers determine disease risk. Inherited genetic variation can be divided into three broad classes: common (>1\%) single nucleotide polymorphisms (SNPs) and copy number variants $(\mathrm{CNVs})$; rare $(<1 \%)$ SNPs and CNVs; and epigenetic modifications. The association of SLE with rare coding variants in three prime repair exonuclease 1 (TREXI) [12], and CNVs in Fc $\gamma$ receptor 3B (FCGR3B) [13], support a role for rare variants and CNVs in susceptibility to this disease. The ability of researchers to assess these sources of genetic variation in comprehensive and systematic studies depends on the available technology. Rare variation, $\mathrm{CNV}$ and epigenetic modification studies are on the horizon, owing to remarkable advances in second- and third-generation sequencing technology.

Our understanding of the role of common variants in complex human diseases and traits has exploded over the past 2 years owing to the development of genome-wide association study (GWAS) technology. GWAS involve the genotyping of hundreds of thousands of SNPs across the genome in large numbers of case and control samples and allow for the discovery of common variants that impact disease risk. To date, there have been four GWAS and a largescale replication effort performed in European populations _[14-18] and one GWAS in a Chinese Han population [19], which together have identified many new loci associated with SLE. Here, we will discuss progress in understanding the contribution of these common alleles to the risk of developing SLE and speculate on how many of them may function in the initiation or progression of disease. In the final section, we will focus on particular risk loci that are shared between SLE and other autoimmune diseases. The identification of such genes may offer insight into the basic mechanisms of tolerance and autoimmunity.

\section{Confirmed SLE risk genes}

Candidate gene studies, the GWAS described above and recent large-scale replication efforts have identified 29 loci that demonstrate 'confirmed' association with SLE, achieving genomewide significance $\left(\mathrm{p}<5 \times 10^{-8}\right)$ in at least one study. A list of these confirmed SLE risk loci is provided in Table 1 and will be discussed in more detail later. It is important to note that for 
the vast majority of confirmed SLE risk loci, the causal variant(s) has not been identified. In those cases, the gene of interest listed in Table 1 therefore represents our 'best guess' based on the strength of the genetic signal, often taken together with inferred functional relevance. Deep resequencing and functional studies will be required to determine the true causal variants at each locus.

Linkage and case-control association studies have identified multiple SLE candidate risk genes (reviewed in [6,20,21]), with at least six loci demonstrating reproducible disease association, including HLA class II haplotypes [22-24], FCGR2A [25,26], protein tyrosine phosphatase, nonreceptor type 22 (PTPN22) [27,28], interferon regulatory factor 5 (IRF5) [29-31], signal transducer and activator of transcription 4 (STAT4) [32] and TNF ligand superfamily 4 (TNFSF4) [33]. The HLA region on the short arm of chromosome 6 (6p21.3) contains hundreds of genes, many of which function in the immune system, including the MHC class I (HLA-A, $-B$ and $-C$ ) and class II ( $H L A-D R,-D Q$ and $-D P$ ) genes. This region is highly polymorphic and, not surprisingly, has been associated with most autoimmune, inflammatory and infectious diseases [34]. There is also a high degree of linkage disequilibrium across the region, making it difficult to localize the specific genetic signal as long stretches of DNA are inherited together as a set, or 'haplotype', of alleles. HLA class II haplotypes involving the HLA-DRBI and HLA$D Q B 1$ loci have been described for their association with SLE and, in particular, haplotypes bearing the $D R B 1 * 1501 / D Q B 1 * 0602(D R 2)$ and $D R B 1 * 0301 / D Q B 1 * 0201$ (DR3) alleles have been associated with risk [35]. Interestingly, $D R 2$ haplotypes are associated with antibodies to the Sm autoantigen, whereas $D R 3$ haplotypes are associated with antibodies to Ro [36]. A highdensity SNP screen across the MHC and the highly polymorphic $H L A-D R B 1$ locus revealed that the most strongly associated $D R B 1$ alleles were $* 0301, * 1501$ and $* 1401$, and provided evidence for independent effects due to variation at the olfactory receptor family 2 , subfamily $\mathrm{H}$, member $2(\mathrm{OR} 2 \mathrm{H} 2)$, camp responsive element-binding protein-like 1 (CREBL1), DQB2 and MHC class I polypeptide-related sequence B $(M I C B)$ loci [37].

The first three GWAS were published simultaneously in early 2008 and resulted in a dramatic leap forward in our understanding of the genetic basis of SLE [38]. In the Hom et al. study [16], more than 500,000 SNPs were genotyped in 1311 SLE cases and 3340 controls from Northern American individuals of European descent and top loci were replicated in 793 cases and 857 controls of Swedish descent. This study identified a SNP that mapped to the interval between B-lymphoid tyrosine kinase $(B L K)$ and $C 8$ orf13 as being associated with SLE. Gene expression datasets generated from Epstein-Barr virus-transformed B-cell lines revealed that the risk allele was associated with lower levels of $B L K$ mRNA expression but higher levels of C8orf13 expression [39]. This study also identified a SNP near the genes encoding integrin $\alpha \mathrm{M}(I T G A M)$ and ITGAX as being associated with SLE. No difference in expression levels of either ITGAM or ITGAX were associated with this variant; however, this SNP correlated with two nonsynonymous variants of ITGAM.

The GWAS performed by the International SLE Genetics Consortium also identified SNPs near ITGAM as being associated with SLE, as well as variants near the phox homology (PX) domain containing serine/threonine kinase $(P X K)$ and $K I A A 1542 / \mathrm{PHD}$ and ring finger domains 1 (PHRF1) [15]. This study genotyped SNPs from 729 SLE cases and 2337 controls and further examined the top loci in two independent replication cohorts. A SNP in KIAA1542/PHRF1 had an $\mathrm{r}^{2}$ value of 0.94 with a SNP in IRF7, a transcription factor critical for the induction of type I interferons (IFN-I). Given the known role of IFN-I in the pathogenesis of SLE (discussed later), IRF7 is a very attractive candidate gene within this locus. A SNP in PXK also showed strong evidence for association with SLE. In addition, variants near pituitary tumortransforming 1 (PTTG1), ubiquitin-conjugating enzyme E2L3 (UBE2L3), autophagy-specific gene 5 (ATG5), PR domain containing 1 (PRDM1) and v-yes-1 Yamaguchi sarcoma viralrelated oncogene homolog $(L Y N)$ achieved a genome-wide significance cut-off of $\mathrm{p}<5 \times$ 
$10^{-8}$ in this study. In a separate publication, a nonsynonymous SNP (rs1143679) in ITGAM that results in an arginine to histidine substitution at amino acid position 77 demonstrated the strongest association with SLE risk [40].

A genome scan published by Kozyrev et al. focused on non-synonymous SNPs in a cohort of 279 SLE cases and 515 controls in a Swedish population [17]. They identified a nonsynonymous substitution $(\mathrm{R} 61 \mathrm{H})$ and variants that affected regulatory sites in B-cell scaffold protein with ankyrin repeats $1(B A N K 1)$ as being associated with SLE. A fourth GWAS was published in late 2008 and genotyped 431 cases and 2155 controls for a genome-wide set of SNPs [14]. This study identified multiple variants near TNF- $\alpha$-induced protein 3 (TNFAIP3) as associated with SLE. Two independent signals were discovered, one of which has also been shown to be associated with RA [41,42]. TNFAIP3 was also shown to be associated with SLE in an independent candidate gene study [43]. The genetics and biology of TNFAIP3 in SLE and RA will be discussed in more detail later in this article.

While the first four GWAS were performed in populations of European descent, a GWAS was recently performed in a Chinese Han population [19]. This study genotyped 1047 SLE cases and 1205 controls and validated seven previously reported loci in this population: $B L K$, IRF5, STAT4, TNFAIP3, TNFSF4, the PRDM1-ATG5 locus on 6q21 and the hypermethylated in cancer (HIC)2-UBE2L3 locus on 22q11.21. Nine new SLE susceptibility loci were identified in this GWAS, including TNFAIP3-interacting protein 1 (TNIP1), RAS guanyl-releasing protein 3 (RASGRP3), Ikaros family zinc finger 1 (IKZF1), leucine-rich repeat-containing 18 (LRRC18), WD repeat and FYVE domain-containing family member 4 (WDFY4), DEAD (Asp-Glu-Ala-Asp)-box polypeptide 6 (DDXØ), v-ets erythroblastosis virus E26 oncogene homolog 1 (ETS1), solute carrier family 15, member 4 (SLC15A4), and regions containing multiple genes on chromosomes 7q11.23 and 16p11.2.

A large-scale targeted replication study of the top SNPs from 2466 loci that demonstrated evidence of an association with SLE in a previous GWAS [16] was performed in order to identify additional risk loci [18]. These SNPs were genotyped in an independent cohort of 1953 cases and 4329 controls from the USA and Sweden. In addition to validating many of the loci described above, this study identified five new susceptibility alleles, including TNIP1,

$P R D M 1$, juxtaposed with another zinc finger gene 1 ( $J A Z F 1)$, ubiquitin-like containing PHD and RING finger domains-binding protein 1 (UHRFIBPI) and IL10. Candidate gene approaches in childhood-onset and adult SLE had suggested an association of IL-1 receptorassociated kinase 1 (IRAKI) [44,45] and later publications implicated the neighboring methyl CpG-binding protein $2(M E C P 2)$ as a candidate gene in this locus $[46,47]$. The replication study confirmed an association with the MECP2-IRAKI locus; however, SNPs near IRAKI demonstrated the strongest evidence for association. Four previously implicated variants near $L Y N$, signal peptide CUB domain EGF-like 1 (SCUBE1), Toll-like receptor 5 (TLR5) and lymphocyte antigen 9 ( $L Y 9$ ) showed no evidence for association in this study.

\section{Candidate genes}

In addition to the confirmed genes listed in Table 1 and discussed previously, the GWAS have led to the discovery of a number of strong candidate genes for association in SLE that fell below the strict $\mathrm{p}<5 \times 10^{-8}$ cut-off of genome-wide significance, many of which probably represent true associations. A list of candidate genes that achieved a p-value cut-off of less than $5 \times 10^{-7}$ in at least one study is provided in Table 2 . The study by Harley et al. reported strong associations for nicotinamide nucleotide adenylyltransferase 2 (NMNAT2), islet cell autoantigen 1 (ICAI), LYN and SCUBE1 [15]. A SNP in IRF8 showed evidence of association in the Graham et al. study [14]. Case-control association studies identified a SNP in the NKX2.5 binding site of the inositol 1,4,5-triphophate receptor 3 (ITPR3) promoter in a 
Japanese population [48], and tyrosine kinase 2 (TYK2) in Swedish, Finnish and Icelandic patients [31]. Finally, the recent replication study identified four new candidate genes, including neutrophil cytosolic factor 2 (NCF2), armadillo repeat-containing 3 (ARMC3), IL-12 receptor $\beta 2$ (IL12RB2) and lysosomal trafficking regulator (LYST), and provided additional evidence for other candidate loci, including NMNAT2, ICA1, TYK2 and IRF8 [18].

Prior to the publication of the GWAS in 2008, there was convincing evidence to support the association of only six of the common alleles described above in SLE: HLA class II haplotypes, FCGR2A, PTPN22, IRF5, STAT4 and TNFSF4. Since then, a total of 29 loci have achieved genome-wide significance for association with SLE and there is strong evidence to support a role for at least 11 other loci as contributing to risk. Despite this tremendous leap forward in the identification of associated genes, much work remains to be done if the critical questions of how these variants function in SLE biology are to be answered. Several recent reviews have applied pathway analysis tools to the genetics of common diseases as an unbiased approach to discover the involvement of known and potentially novel pathways in disease pathogenesis $[49,50]$. In other words, what can the susceptibility loci tell us about the biology of the disease? Here, we take the opposite (and, admittedly, much more biased) approach and instead focus on what the biology of SLE can tell us about potentially novel functions of the newly discovered SLE risk loci. In particular, we focus on evidence for the involvement of many of these genes in two pathways known to be central to the pathogenesis of this autoimmune disease: TLR/ IFN-I signaling and lymphocyte development and signaling.

\section{Functional implications of SLE susceptibility genes}

\section{TLR \& IFN-I in the pathogenesis of SLE}

The biological role of IFN-Is in the pathogenesis of SLE in humans has been studied extensively (reviewed most recently in [51]). An increase in circulating IFN- $\alpha$ in the serum of lupus patients was first noted by Hooks et al. in 1979 and levels were later shown to correlate with disease activity [52-54]. Peripheral blood mononuclear cells (PBMCs) from SLE patients display an IFN-I-inducible gene signature ([55-58] and reviewed in [59]) and increased levels of IFN-Iinducible chemokines in SLE sera are biomarkers for active disease [60,61]. This interferon (IFN)-inducible gene-expression signature defines a subgroup of patients with severe SLE characterized by renal disease, complement activation and autoantibody production to RNAassociated autoantigens [62]. A subset of patients treated with recombinant IFN- $\alpha$ for nonautoimmune disorders such as hepatitis develop a lupus-like syndrome that is reversible when IFN- $\alpha$ therapy is discontinued (reviewed in [63]), suggesting that IFN-Is play a causative role in SLE pathogenesis.

As described previously, over the years many groups have noted hyperactivation of the IFNI pathway in SLE patients, however, it was the relatively recent characterization of the nucleic acid-sensing TLRs that has provided insight into the elusive mechanism of activation of this pathway in SLE. TLRs are a family of pattern-recognition receptors that are activated by conserved molecular patterns present on microbes, such as bacterial and viral nucleic acids. The endosomal location of the nucleic acid-sensing TLRs (TLR3, TLR7, TLR8 and TLR9) is critical for the prevention of recognition of self-derived nucleic acids [64]. A serum factor in SLE patients that induced IFN-I production in normal PBMCs was identified in the form of circulating ICs that contain nucleic acids [65-71]. The induction of IFN-I in plas-macytoid dendritic cells (pDCs) by SLE-ICs requires FCGR2A, which delivers ICs to endosomes, and either the dsDNA receptor, TLR9, in the case of DNA-associated autoantigens [72], or the ssRNA receptor, TLR7, in the case of RNA-associated autoantigens $[73,74]$. An autoreactive $\mathrm{B}$ cell can also become activated by these autoantigens by dual engagement of the B-cell receptor (BCR), which internalizes bound antigen into endosomes, and TLR7 or TLR9 [75, 76]. Interestingly, duplication of the $T L R 7$ gene is sufficient for the induction of autoantibodies 
against RNA-containing autoantigens and the dysregulation of myeloid cells in mice carrying the Y chromosome-linked modifier Yaa [77-79]; however, some studies suggest that other genes at this locus may also contribute to inflammation in this model [80,81]. In addition, IFNI itself is critical for the upregulation of TLRs in B cells and their subsequent maturation into IgG-secreting plasma cells [82-86]. Taken together, these studies highlight the critical role that TLRs play in the induction of IFN-I in pDCs and in the activation of autoreactive B cells by nucleic acid-containing auto-antigens and may explain how this subset of molecules becomes the target of autoantibodies in SLE.

\section{SLE risk genes in TLR signaling}

Given the known role of TLRs and IFN-Is in SLE pathogenesis, it is hypothesized that mutations resulting in the hyperactivation of these pathways may predispose individuals to the development of SLE. Figure 1 is a simplified diagram of the TLR and IFN signaling pathways, highlighting the roles that a number of the confirmed and candidate SLE risk genes may play. Briefly, TLR7/8 and TLR9 signal through the adaptor protein myeloid differentiation primary response gene 88 (MyD88), the kinases IRAK1 and IRAK4, and the E3 ubiquitin ligase TNF receptor-associated factor 6 (TRAF6). Stimulation of TLRs by nucleic acids activates two main families of transcription factors; namely, NF- $\mathrm{KB}$, which results in the induction of proinflammatory cytokines such as IL-1, IL-6, IL-12 and TNF- $\alpha$, and IRF, which results in the induction of IFN-I. The proteins of the IFN-I family, which include many subtypes of IFN- $\alpha$ and the single IFN- $\beta$ protein, bind to and signal through the IFN-I receptor (IFNAR), resulting in activation of the Janus kinases (JAK), JAK1 and TYK2, and the STAT transcription factors, STAT1, STAT2 and STAT4. Polymorphisms in many of these well-characterized TLR and IFN signaling intermediates have been shown to be associated with SLE, including IRF5, a variant near IRF7 (PHRF1), IRAK1, TYK2 and STAT4. In addition, there is evidence for the involvement of many other SLE risk loci in these pathways, including IRF8, TNFAIP3, TNIP1, UBE2L3, ATG5, FCGR2A, LYN, TNFSF4, IL10, NCF2, IL12RB2, ITGAM, IKZF1, PRDMI and ETS1.

Interferon regulatory factors are a family of transcription factors that play important roles in the induction of IFN-I and downstream IFN-inducible genes (reviewed in [87]). IRF7 is essential for TLR-induced MyD88-dependent IFN-I production by pDCs [88], which are the major producers of IFN-I (reviewed in [89]). Importantly, both IRF5 and IRF7 are critical for the induction of IFN-I in pDCs by RNA-containing ICs [90]. The production of many proinflammatory cytokines, including IL-1, IL-12, TNF- $\alpha$ and IL-6, is also impaired in conventional DCs, pDCs, macrophages and B cells from $\mathrm{Irf5}^{-1-}$ mice following TLR stimulation [91]. Mice genetically deficient for Irf8 completely lack pDCs, indicating the importance of this transcription factor for the development of this IFN-producing DC subset [92-94]. There is also evidence that IRF8 participates directly in TLR signaling as it interacts with TRAF6 [95] and $I r f 8^{-1}$ conventional DCs fail to produce proinflammatory cytokines upon TLR9 stimulation but are responsive to TLR4 stimulation [96].

The IRAK family members, which include IRAK1, IRAK2, IRAKM and IRAK4, are serine/ threonine protein kinases that play critical roles in signaling through TLRs and the IL-1 receptor family members IL-1R, IL-18R and IL-33R (reviewed in [97]). IRAK1 recruits key components of the TLR signaling complex, including MyD88, IRAK4 and TRAF6 [98,99]. Macrophages from Irakl-deficient mice only have partial defects in NF-kB activation following TLR or IL-1 stimulation [100,101], and it has been suggested that IRAK1 and IRAK2 function redundantly in TLR-induced NF- $\kappa B$ signaling downstream of IRAK4 [102]. Interestingly, despite only minor defects in proinflammatory cytokine induction, IFN- $\alpha$ production is completely abrogated in $\operatorname{Irak1^{-/}}{ }^{-}$mice following TLR7 and TLR9 stimulation 
in vitro and upon intravenous injection of a TLR7 agonist, indicating a specific requirement for IRAK1 in IFN-I production in vivo [100].

The ubiquitination of signaling molecules is an integral component of TLR signaling (reviewed in [103]), and several SLE risk genes play key roles in this process. TRAF6 is an E3 ubiquitin ligase and catalyzes the addition of activating K63-linked polyubiquitin chains onto target proteins. TNFAIP3 is a critical negative regulator of TLR signaling through its ability to deubiquitinate TRAF6 (discussed in greater detail later). TNIP1 (also called ABIN1) was first identified as a TNFAIP3-interacting protein and promotes the inhibition of TNF-induced NF$\kappa \mathrm{B}$ activation and apoptosis [104-106]. However, whether TNIP1 has a role in TLR-induced NF- $\kappa \mathrm{B}$ activation or IFN-I production has not yet been examined. UBE2L3 is an E2 ubiquitinconjugating enzyme. Although UBE2N (UBC13) is considered to be the canonical E2 involved in TRAF6-mediated NF- $\mathrm{KB}$ induction [107], at least one study has demonstrated a role for UBE2L3 in the activity of TRAF6-mediated K63-linked polyubiquitination [108]. As the ubiqutination of IRF5 and IRF7 by TRAF6 appears to be key to their activity [109,110], it is possible that UBE2L3 plays a role in the induction of IFN-I.

Studies using $\operatorname{Atg} 5^{-1-}$ pDCs have revealed a surprising requirement for autophagy in IFN-I production by pDCs in response to viral infection [111]. The authors hypothesize that ATG5 may be involved in sorting TLRs to the particular endocytic compartment in which TLR signaling leads to IFN-I production. As spatiotemporal regulation of MyD88-dependent TLR signaling is crucial for IFN production by pDCs [112], functional variants of ATG5 could potentially alter the threshold for IFN-I induction by self-nucleic acids by retaining nucleic acid-sensing TLRs in endocytic vesicles.

One study has demonstrated that the crosslinking of blood DC antigen 2 (BDCA2) on the surface of $\mathrm{pDCs}$ leads to the induction of IFN-I through a mechanism involving a 'BCR-like signalosome' including the SLE risk gene $L Y N$ [113]. It is therefore possible that a functional allele of $L Y N$ could promote both increased BCR activation and also production of IFN-I. Finally, although FCGR2A is not normally thought to play a direct role in TLR signaling, several studies have shown that FCGR2A expression on pDCs is critical for the induction of IFN-I by SLE autoantibodies owing to its ability to bind and internalize circulating ICs and deliver associated nucleic acids to endosomal TLRs [66,72].

\section{SLE risk genes in IFN-I signaling}

Several genes that function downstream of the IFN-I receptor are also associated with SLE. As described above, binding of IFN-I to the receptor triggers a JAK/STAT signaling cascade through TYK2 and STAT4. SLE patients that carry the STAT4 risk variant have increased expression of downstream IFN-I-regulated genes in vivo compared with patients who do not carry the allele [114]. IKZF1 (also called Ikaros) is a transcription factor involved in the development of cells of the lymphoid lineages [115] and has also been shown to play a role in transcriptional regulation of STAT4 [116]. PRDM1 (also known as B-lymphocyte-induced maturation protein [BLIMP]1) is a transcriptional repressor that binds to the positive regulatory domain (PRD) I of the IFN- $\beta$ promoter and acts as a negative regulator of IFN- $\beta$ gene transcription [117-119]. PRDM1 is also essential for the differentiation of B cells into antibody-secreting plasma cells (reviewed in [120]). ETS1 has been shown to bind to IFNstimulated response elements (ISRE) and may function as a negative regulator of IFN-Iinduced transcription [121]. ETS1 is also involved in the development and differentiation of many different cells of the immune system, including $\mathrm{T}$ cells, B cells, plasma cells, natural killer cells and natural killer T cells [122].

Given the pleiotropic immunomodulatory effects of IFN-Is, it is not surprising that many SLE risk genes involved in other aspects of the innate or adaptive immune system are themselves 
IFN-I-inducible. IFN-I upregulates the expression of many of the components of TLR and IFN signaling listed above as part of a positive feedback loop. IFN-I signaling can also promote the upregulation of MHC class II (HLA-DRB1), costimulatory molecules (TNFSF4), other cytokines and cytokine receptors (IL-10 and IL-12RB2), and adhesion molecules (ITGAM [123]), as well as promoting the maturation of monocytes into mature DCs, T cells into Th1 cells and B cells into antibody-secreting plasma cells. Dysregulation of the TLR or IFN-I pathways could therefore have broad effects on the immune response and hence contribute to the risk of developing autoimmunity.

\section{SLE risk genes in lymphocyte development \& signaling}

Signaling through the antigen receptors on the surface of $\mathrm{B}$ and $\mathrm{T}$ cells promotes the development, differentiation and activation of these critical mediators of the adaptive immune response. The signaling pathways downstream of the BCR or T-cell receptor (TCR) are extremely complex and thus many layers of regulation exist in order to prevent their inadvertent activation by self-antigens. It is therefore hypothesized that alterations in the strength of signal during development may alter the BCR and TCR repertoires, or alternatively may lower thresholds for activation by self in the periphery, leading to breaks in tolerance to self antigens.

One of the strongest genetic signals in the susceptibility to all autoimmune diseases is the HLA locus. MHC class II mediates the presentation of antigen to $\mathrm{CD}^{+} \mathrm{T}$ cells and the $\mathrm{MHC}$ genotype therefore drives the spectrum of peptides presented and, ultimately, the ability of $\mathrm{T}$ cells to respond to particular antigens. It is hypothesized that different MHC alleles will have differing abilities to bind and present self-peptides, and therefore offer either susceptibility to, or protection from, autoimmune disease. The MHC genotype may contribute to the breaking of tolerance in at least two ways: first, a particular allelic variant could present an autoantigenic peptide to an autoreactive $\mathrm{T}$ cell and promote its activation in the periphery. Second, the presentation of self-peptides by specific MHC alleles in the thymus could either promote the positive selection of self-reactive $\mathrm{T}$ cells or fail to negatively select autoreactive $\mathrm{T}$ cells. The highly polymorphic MHC alleles therefore play critical roles in both shaping the T-cell repertoire during development in the thymus and in promoting their activation in the periphery. ATG5 is also likely to participate in antigen presentation to $\mathrm{CD}^{+} \mathrm{T}$ cells owing to its known role in autophagy, a cellular process by which proteins in the cytosol are delivered to the lysosomes for degradation. In antigen-presenting cells (APCs) such as DCs, autophagy allows for the cross-presentation of cytosol-derived peptides on MHC class II (reviewed in [124]).

Several SLE risk genes are thought to function downstream of antigen receptors, including $B L K, P T P N 22, R A S G R P 3, B A N K 1, L Y N, I T P R 3$ and TNFSF4. The function of BLK and $P T P N 22$ are discussed later in this article as variants in these genes have been implicated in multiple autoimmune diseases. Ras signaling plays an important role in both BCR and TCR signaling, and RASGRP3 links BCR signaling to the phospholipase C (PLC) 2 2-diacylglycerol (DAG) pathway [125]. Activation through the BCR leads to phosphorylation of the scaffold protein BANK1, which in turn promotes LYN-mediated phosphorylation of ITPR3, ultimately resulting in calcium mobilization [126]. TNFSF4 (also called OX40L) is a costimulatory molecule on the surface of APCs that has been shown to both promote the activation of conventional $\mathrm{T}$ cells and suppress the function of T-regulatory cells (reviewed in [127]). Taken together, the association of multiple genes in lymphocyte signaling pathways with risk of SLE suggests that altering signaling thresholds of lymphocytes is an important mechanism in the breakdown of tolerance in this disease.

\section{SLE risk genes with unknown functions}

Although many SLE susceptibility genes have been implicated in innate and adaptive immunity as previously outlined, many have no known function or are have functions that are not easily 
extrapolated to the immune system. For instance, JAZF1 is a transcriptional repressor that has no known immune function to date [128]. The variant identified as being associated with SLE in this locus has also been implicated in the risk of Type 2 diabetes [129] and in height variation [130], complex traits that are not typically thought to result from variation in immune-related genes. The association of JAZF1 and other risk alleles with SLE implies that they may have important roles in the function of the immune system. A clear understanding of the biology of the disease being studied may also lead to the discovery of novel functions for already wellcharacterized genes. For example, mutations that lead to a complete deficiency of the protein encoded by the LYST gene result in the disorder Chediak-Higashi syndrome (reviewed in [131]). Studies in this disease have revealed that LYST functions in lysosomal trafficking in many immune cells, a process that is also crucial in the activation of TLRs by self-nucleic acids in SLE [64]. However, much work remains to be done in order to fully understand how each variant functions in the pathogenesis of SLE.

\section{Overlap of SLE with other autoimmune \& inflammatory disorders}

\section{Shared autoimmune loci}

The immune system is in a constant struggle to maintain a balance between immunity (the elimination of foreign pathogens) and tolerance (the lack of response to self-tissue). When the mechanisms regulating the immune response fail, the inflammatory destruction of self-tissues can occur. Recent studies have suggested that many chronic autoimmune and inflammatory disorders may stem from common pathogenic mechanisms that result from variation in shared genetic pathways (reviewed in $[132,133]$ ). Interestingly, many immune-related disorders demonstrate co-occurrence within both individuals and families. For example, asthma, Type 1 diabetes (T1D) and autoimmune thyroid disease (AIT) have been shown to co-occur in individuals with rheumatoid arthritis (RA), and AIT, T1D, SLE and multiple sclerosis (MS) all demonstrate familial clustering with RA [134-136]. Recent evidence supports the idea that some genetic variants are associated with multiple autoimmune diseases, whereas others are specific for particular disorders. For example, a functional SNP in PTPN22 is associated with risk of T1D, RA, SLE and Hashimoto's thyroiditis, but not MS, in a collection of families with a history of multiple auto-immune diseases, suggesting a common underlying etiology for some, but not all, autoimmune disorders [137]. Here, we discuss the genetic evidence for overlap between SLE and other autoimmune and inflammatory disorders. Table 3 contains a list of genes that have demonstrated an association with SLE and at least one other autoimmune disease. Putative functions of each gene are given and are classified below into a few broad categories for the purpose of this discussion: lymphocyte signaling (PTPN22, SH2B adaptor protein 3 [SH2B3], BLK and PRDMI), Th1 development (STAT4, IL12B and IL10) and innate immunity (TNIP1, IRF8, TYK2, TNFAIP3, IFN induced with helicase C domain 1 [IFIH1], complement factor B $[C F B], F C G R 2 A$ and macrophage migration inhibitory factor $[M I F])$. In addition, SNPs near CLEC16A, a C-type lectin domain family member with no known function, have been associated with SLE [18], MS [138], T1D [138,139] and Addison's disease [140]; SNPs near the predicted gene, C10orf67, are associated with SLE [18] and Crohn's disease (CD) [141].

\section{Lymphocyte signaling genes as shared autoimmune loci}

Protein tyrosine phosphatase, nonreceptor type 22 is a protein tyrosine phosphatase that functions as a negative regulator of $\mathrm{T}$ - and $\mathrm{B}$-cell responses through its ability to dephosphorylate key downstream signaling molecules, including lymphocyte-specific protein tyrosine kinase (LCK), protein-tyrosine kinase fyn (FYN) and $\zeta$-chain (TCR)-associated protein kinase $70 \mathrm{kDa}$ (ZAP70) [142]. A missense mutation results in a change from an arginine to a tryptophan at position 620 within a proline-rich region. The functional consequences of this substitution appear to be a decreased ability to bind C-terminal Src tyrosine kinase, an 
important negative regulator of lymphocyte-specific protein tyrosine kinase [143,144]. The consequences of the substitution are controversial, with decreased activation through both the BCR and TCR reported by some [145-147] and conversely, increased TCR signaling reporter by others [148]. The $620 \mathrm{~W}$ allele has been associated with risk for SLE, T1D [143], RA [144] and Graves' disease [149], but interestingly is associated with protection against CD [150]. In addition, there is evidence that this allele is not associated with other autoimmune diseases, such as celiac disease [151] and MS [137]. Recently, a rare missense substitution (R263Q) in PTPN22 was shown to reduce phosphatase activity and was associated with protection from SLE [152].

SH2B adaptor protein 3 (also called LNK) is an SH2-domain containing protein that functions as an adaptor protein in TCR, BCR, growth factor and cytokine receptor signaling pathways and therefore plays an important role in hematopoietic homeostasis [153-155]. Mice genetically deficient for $\mathrm{SH} 2 \mathrm{~B} 3$ are hypersensitive to stimulation with multiple cytokines [153]. SH2B3 also functions as a regulator of T-cell signaling as overexpression of SH2B3 inhibits the activation of nuclear factor of activated T cells (NFAT) following TCR stimulation in vitro [156]. Variants that affect $S H 2 B 3$ function could therefore alter the signaling thresholds through many different receptors on cells of both the lymphoid and myeloid lineage. A nonsynonymous SNP that leads to a R262W substitution in SH2B3 is associated with SLE, T1D [157] and celiac disease [158], and occurs in the pleckstrin homology domain, which is known to be important for targeting to the plasma membrane $[157,159,160]$.

B-lymphoid tyrosine kinase is a Src family kinase that is hypothesized to transduce signals downstream of the BCR. The expression of BLK is highly restricted to the B-cell lineage [161] and the risk allele is associated with reduced expression of BLK in transformed B-cell lines [16]. This SNP has demonstrated association with SLE, RA [162] and antiphospholipid syndrome [163]. However, exactly how decreased expression of BLK may predispose an individual to the development of autoimmunity is unknown, as mice genetically deficient for Blk display no obvious phenotypes in B-cell development or function [164].

\section{Th1 cells in the predisposition to autoimmunity}

The contribution of different subsets of T-helper cells to the pathogenesis of inflammatory diseases has been the subject of much research over the years and, more recently, much debate [165]. The Th1-Th2 model was first proposed by Coffman and Mosmann in 1986 and postulates that $\mathrm{CD} 4^{+} \mathrm{Th} 1$ cells drive the cell-mediated immune responses that lead to tissue damage and the particular IgG responses thought to play a role in many inflammatory diseases, whereas $\mathrm{CD}^{+} \mathrm{Th} 2$ cells drive the production of certain antibodies (IgE) that predominantly underlie allergic responses $([166,167]$ and reviewed in $[168])$. In recent years, the characterization of novel subsets of T helper cells, most notably Treg and Th17 cells, has led to a major paradigm shift in T-cell biology.

Although Th17 cells have been shown to be central to the pathogenesis of many autoimmune diseases, including MS, RA, inflammatory bowel disease, asthma and psoriasis, the data supporting a role for this population in SLE are not as clear. Accordingly, while there is a clustering of variants in Th17 pathway genes in the aforementioned diseases, these loci do not appear to predispose to risk of SLE, with the possible exception of $I L 12 B$ as described below $[169,170]$. However, variants in genes known to contribute to the development of Th1 cells have been shown to be associated with SLE and other autoimmune diseases, including STAT4 [32], IL12B [171,172] and IL10 [173,174]. IL-12 and IL-23 are cytokines that share the subunit (p40) encoded by IL12B. When IL-12B dimerizes with the p35 subunit (IL-12A), signaling through the receptor induces Th1 differentiation, which requires STAT4. However, when IL-12B dimerizes with the $\mathrm{p} 19$ subunit (IL-23A), signaling through the IL-23 receptor and STAT3 promotes Th17 differentiation and survival, which requires STAT3. IL-10 is a 
broad immunosuppressive cytokine and, in particular, regulates the development of Th1 cells [175].

\section{Innate immunity genes in autoimmune disease}

Several shared autoimmune loci function in innate immunity and putative functions for TNIP1 (also associated with psoriasis [172]), IRF8 (also associated with MS [176]), TYK2 (also associated with MS [177]) and TNFAIP3 are discussed elsewhere in this review. A missense allele of $I F I H I$ is associated with risk for T1D [178], Graves' disease [179] and SLE [18]. IFIH1 (also called MDA5) is a cytoplasmic RNA sensor that promotes IFN-I production when activated by viruses [180]. As the innate immune response to viral infection is hypothesized to play a role in the pathogenesis of multiple autoimmune diseases, the inappropriate activation of nucleic acid sensors such as TLRs and IFIH1 may contribute to a general predisposition towards autoimmunity [181]. A missense allele $(R 32 Q)$ of $C F B$, an activator of the alternative complement pathway, is associated with protection from age-related macular degeneration (AMD) and SLE, and has reduced hemolytic activity [182,183]. Defects in complement components have been associated with both SLE and AMD and, interestingly, the incidence of SLE is increased in AMD patients relative to matched controls, suggesting a common pathogenic mechanism between these two diseases [184]. MIF is an immunoregulatory cytokine that functions in both innate and adaptive immunity and is expressed by many immune cells such as monocytes, macrophages, and $\mathrm{T}$ and $\mathrm{B}$ lymphocytes. Polymorphisms in the MIF gene have been associated with multiple autoimmune and inflammatory diseases (reviewed in [185]), including SLE [186], RA [187], CD [188], psoriasis [189] and celiac disease [190].

\section{Overlap of SLE with RA}

Systemic lupus erythematosus and RA in particular share many clinical, serological and phenotypic features, and studies have demonstrated familial aggregation of RA with SLE [3]. A recent population-based study demonstrated that by 25 years after RA incidence, four or more SLE features were observed in $15.5 \%$ of RA patients, highlighting the substantial overlap between these two diseases [191]. It is therefore believed that common pathogenic mechanisms underlie the susceptibility to, and progression of, these two diseases. Genetic data support this model as several loci have been identified that are associated with the risk of both SLE and RA, including HLA haplotypes, BLK [162], PTPN22 [144], STAT4 [32], FCGR2A [192], PRDM1 [192] and TNFAIP3. IRF5 has also been shown to be associated with RA in some studies [193,194], however, others have failed to demonstrate an association [195,196]. Although these two diseases do share some overlapping phenotypes, many key features are distinct and, consistent with this, many loci appear to be associated exclusively with one disease and not the other [197]. The genes implicated in susceptibility to SLE and RA are known to play a role in pathways critical to the induction and maintenance of tolerance, including lymphocyte selection (HLA), activation (BLK, PTPN22) and differentiation (PRDM1, $S T A T 4$ ). As detailed descriptions of the putative functions of many of these genes and speculations on how they may predispose to autoimmunity have been discussed in detail elsewhere in this review, next we focus on the genetics and biology of TNFAIP3 in RA and SLE.

\section{TNFAIP3 in the susceptibility to SLE \& RA}

As described above, TNFAIP3 is a negative regulator of NF- $\mathrm{KB}$, a key transcription factor in the inflammatory response. Variants near TNFAIP3 have been associated with risk for multiple auto-immune diseases, including RA [41], SLE [14,43], T1D [198], psoriasis [172], celiac disease [199] and CD [200]. TNFAIP3 is also frequently inactivated in human B-cell lymphomas and, therefore, contributes to the persistent NF- $\mathrm{KB}$ activation known to play a role 
in the development and progression of cancer [201,202]. Regulation of NF- $\mathrm{kB}$ by TNFAIP3 is therefore central to the pathogenesis of a spectrum of human diseases where inflammation is known to play a role (reviewed in [203]).

NF- $\kappa \mathrm{B}$ is a transcription factor that is activated by many different stimuli, including TLR agonists, TNF and IL-1. A crucial mechanism in the regulation of this pathway is the ubiquitination of key signaling components by both K48-linked polyubiquitin chains, which target a protein for degradation, and K63-linked polyubiquitin chains, which are associated with protein activation. A20, the protein encoded by TNFAIP3, is a ubiquitin-editing enzyme, as it contains an $\mathrm{N}$-terminal ovarian tumor domain that functions as a deubiquitinase by removing K63-linked ubiquitin chains, and a C-terminal zinc finger domain that functions as an E3 ubiquitin ligase by catalyzing the addition of K48-linked ubiqutin chains to target proteins. These seemingly opposing functions promote the inactivation and subsequent degradation of key NF- $\mathrm{kB}$ signaling components, including receptor-interacting protein 1 (RIP1), which mediates signaling downstream of TNFR [204], and TRAF6, which has been seen to mediate signaling downstream of TLRs and IL-1R [205,206]. A20 also plays an important role in TNF-induced apoptosis [207]: $A 2 \mathrm{O}^{-/-}$mice develop severe inflammation in multiple organs and are hypersensitive to sublethal doses of the TLR4 agonist lipopolysaccharide and TNF, demonstrating the crucial role of this gene in the regulation of inflammation in vivo [208].

A GWAS in RA and data from the Wellcome Trust Case Control Consortium of seven common inflammatory diseases identified two independent variants at $6 \mathrm{q} 23$ that fell further than 150 $\mathrm{kb}$ from the nearest genes, TNFAIP3 and oligodendrocyte transcription factor $3[41,42,200]$. Given that inhibition of TNF- $\alpha$ is an effective therapy for severe RA [209], TNFAIP3 emerged as a strong candidate gene in this region. A 'protective' haplotype tagged by rs10499194 and a 'risk' haplotype tagged by rs6920220 were defined for RA. TNFAIP3 was subsequently identified as being associated with SLE in two studies [14,43]. Taken together with data for RA, the results suggest a genetic model of three alleles with independent effects at the TNFAIP3 locus: a risk allele defined by rs6920220 for both RA and SLE, a protective allele defined by rs 10499194 in RA that was not present in SLE, and an SLE-specific risk haplotype defined by the minor alleles rs 10499197 and rs77949323. The genetics of this locus are therefore very complex and suggest that, while variants near TNFAIP 3 are associated with a generalized susceptibility to multiple inflammatory conditions, disease-specific polymorphisms may influence the development or progression of particular autoimmune phenotypes. A nonsynonymous SNP that results in a phenylalanine to cysteine substitution at amino acid 127 in the ovarian tumor domain was associated with risk for SLE and decreased the ability of the A20 protein to inhibit TNF-induced NF- $\kappa B$ activity in an in vitro system [43]. A hypomorphic allele of TNFAIP3 that results in decreased expression or activity could lead to dysregulation of both TNF and TLR-induced NF- $\mathrm{KB}$ signaling, as well as TNF-induced apoptosis and TLR-induced IFN production, resulting in a generalized susceptibility to inflammation.

\section{Expert commentary}

In this review, we have outlined and reviewed the identification of over 40 loci implicated in the risk for SLE and other auto-immune and inflammatory diseases. We have also speculated about how candidate genes within these loci may function in the development and progression of autoimmunity, with the goal of identifying testable hypotheses for future experiments.

The rapidly growing catalog of loci associated with auto-immunity represents a key early step in our understanding of these diseases, however, the vast majority of the genetic burden of this disease has yet to be discovered. In a recent large SLE genetic study, it was estimated that the 
26 confirmed SLE loci accounted for only $8 \%$ of the total genetic susceptibility to SLE [18]. There is much debate in the field regarding the potential sources of this 'missing heritability' in complex human diseases and traits [210], which might include the presence of a large number of variants with small effects, rare variants with larger effects, structural variants such as CNVs that are not captured on current platforms, epigenetic modifications, the inability to detect gene-gene interactions, imprecise phenotyping and disease heterogeneity, and the presence of suppressor alleles in control populations.

Identifying the causal variant at each locus and understanding the biology of how the variant alters the risk of developing disease will provide a major advance in our ability to translate genetic associations into new therapeutic targets and diagnostic applications. Of the 29 known SLE loci, few causal variants have been identified $[26,29,30,40]$ and detailed biological mechanisms for how the causal variants alter disease risk are understood for even fewer of the loci. The identification of causal variants will be greatly enhanced by emerging 'nextgeneration' sequencing technologies [211] and public efforts such as the '1000 Genomes Project' [301]. However, proving the biological mechanism of candidate causal variants will be arduous. Among the challenges are the expected modest effect that common variants may have on protein function or expression, with some effects visible only under particular environmental conditions or perturbations, certain genetic backgrounds, developmental stages or cell types. One success story that illustrates these challenges is the identification of celltype-specific phenotypes in the surface expression of IL-R2A based on the genotype at the ILR2A locus, which has been shown to be associated with T1D and MS [212]. This study relied on access to a large collection of approximately 5000 normal volunteers who were recalled on the basis of risk and protective haplotypes to donate fresh blood samples as the phenotype of interest was not present in cryopreserved samples from the same donors. In addition, the ILR2A genotype accounted for only $18 \%$ of the variation in the level of surface expression observed, suggesting a crucial role for confounding genetic and environmental factors.

\section{Five-year view}

In the next 5 years, we expect progress to be made in identifying additional risk loci, both by larger genome-wide and targeted association studies, and by examining other sources of genetic variation, including rare variants, $\mathrm{CNVs}$ and epigenetics. In addition, causal variant identification will be greatly enhanced by near-complete catalogs of human variation and nextgeneration sequencing technologies, and better understanding the biological mechanism of causal variants by the establishment of large 'bio-banks' of normal individuals. These will be important incremental efforts in our quest to fully understand the underlying genetic and environmental causes of lupus, and to apply this knowledge to the development of new therapies and preventive measures.

\section{Key issues}

- Recent genome-wide association studies in systemic lupus erythematosus (SLE) have brought the current total of confirmed susceptibility alleles achieving genome-wide significance $\left(\mathrm{p}<5 \times 10^{-8}\right)$ in this disease to 29 .

- An additional 11 candidate loci have demonstrated strong evidence of association with SLE $\left(\mathrm{p}<5 \times 10^{-7}\right)$, probably representing true genetic signals.

- The induction of type I IFN following stimulation of Toll-like receptors by nucleic acid-associated autoantigens is critical to the pathogenesis of SLE. It is hypothesized that genetic variation resulting in hyperactivation of this pathway predisposes individuals to SLE. Accordingly, there is evidence to support a role for several SLE risk genes in this pathway. 
- SLE shares many susceptibility alleles with other autoimmune and inflammatory conditions. The identification and functional characterization of shared autoimmune loci may provide insight into the common pathogenic mechanisms that promote the breakdown of immunological tolerance.

- Many challenges remain in identifying the causal variant(s) at each locus in SLE and other complex diseases. Furthermore, as the effect size of each common genetic variant is small and confounded by other genetic and environmental factors, translating a genotype into a measurable phenotype is an extremely complex problem.

- Deep resequencing efforts using emerging 'next-generation' sequencing technologies have the potential to allow the detection of rare genetic variants that demonstrate association with disease, as well as assisting in the identification of causal alleles.

\section{References}

Papers of special note have been highlighted as:

- of interest

•• of considerable interest

1. Rus, V.; Maury, EE.; Hochberg, MC. The epidemiology of systemic lupus erythematosus. In: Wallace, DJ.; Hahn, BH., editors. Dubois' Lupus Erythematosus. Lippincott Williams \& Wilkins; PA, USA: 2007. p. 34-44.

2. von Muhlen CA, Tan EM. Autoantibodies in the diagnosis of systemic rheumatic diseases. Semin Arthritis Rheum 1995;24(5):323-358. [PubMed: 7604300]

3. Alarcon-Segovia D, Alarcon-Riquelme ME, Cardiel MH, et al. Familial aggregation of systemic lupus erythematosus, rheumatoid arthritis, and other autoimmune diseases in 1,177 lupus patients from the GLADEL cohort. Arthritis Rheum 2005;52(4):1138-1147. [PubMed: 15818688]

4. Deapen D, Escalante A, Weinrib L, et al. A revised estimate of twin concordance in systemic lupus erythematosus. Arthritis Rheum 1992;35(3):311-318. [PubMed: 1536669]

5. Block SR, Winfield JB, Lockshin MD, D'Angelo WA, Christian CL. Studies of twins with systemic lupus erythematosus. A review of the literature and presentation of 12 additional sets. Am J Med 1975;59(4):533-552. [PubMed: 1101680]

6. Harley JB, Moser KL, Gaffney PM, Behrens TW. The genetics of human systemic lupus erythematosus. Curr Opin Immunol 1998;10(6):690-696. [PubMed: 9914226]

7. Pettigrew HD, Teuber SS, Gershwin ME. Clinical significance of complement deficiencies. Ann NY Acad Sci 2009;1173:108-123. [PubMed: 19758139]

8. Slingsby JH, Norsworthy P, Pearce G, et al. Homozygous hereditary C1q deficiency and systemic lupus erythematosus. A new family and the molecular basis of $\mathrm{Clq}$ deficiency in three families. Arthritis Rheum 1996;39(4):663-670. [PubMed: 8630118]

9. Provost TT, Arnett FC, Reichlin M. Homozygous C2 deficiency, lupus erythematosus, and anti-Ro (SSA) antibodies. Arthritis Rheum 1983;26(10):1279-1282. [PubMed: 6605148]

10. Fielder AH, Walport MJ, Batchelor JR, et al. Family study of the major histocompatibility complex in patients with systemic lupus erythematosus: importance of null alleles of $C 4 A$ and $C 4 B$ in determining disease susceptibility. Br Med J Clin Res Ed 1983;286(6363):425-428.

11. Davies EJ, Steers G, Ollier WE, et al. Relative contributions of HLA-DQA and complement C4A loci in determining susceptibility to systemic lupus erythematosus. Br J Rheumatol 1995;34(3):221225. [PubMed: 7728395]

12 . Lee-Kirsch MA, Gong M, Chowdhury D, et al. Mutations in the gene encoding the $3^{\prime}-5^{\prime}$ DNA exonuclease TREX1 are associated with systemic lupus erythematosus. Nat Genet 2007;39(9): 
1065-1067. Implicates a rare variant of three prime repair exonuclease (TREX)1 in systemic lupus erythematosus (SLE). [PubMed: 17660818]

13. Aitman TJ, Dong R, Vyse TJ, et al. Copy number polymorphism in Fcgr3 predisposes to glomerulonephritis in rats and humans. Nature 2006;439(7078):851-855. [PubMed: 16482158]

14. Graham RR, Cotsapas C, Davies L, et al. Genetic variants near TNFAIP3 on 6q23 are associated with systemic lupus erythematosus. Nat Genet 2008;40(9):1059-1061. [PubMed: 19165918]

15•. Harley JB, Alarcon-Riquelme ME, Criswell LA, et al. Genome-wide association scan in women with systemic lupus erythematosus identifies susceptibility variants in ITGAM, PXK, KIAA1542 and other loci. Nat Genet 2008;40(2):204-210. First generation of genome-wide association studies in SLE. [PubMed: 18204446]

16•. Hom G, Graham RR, Modrek B, et al. Association of systemic lupus erythematosus with C8orf13BLK and ITGAM-ITGAX. N Engl J Med 2008;358(9):900-909. Part of the first generation of genome-wide association studies in SLE. [PubMed: 18204098]

17•. Kozyrev SV, Abelson AK, Wojcik J, et al. Functional variants in the B-cell gene BANK1 are associated with systemic lupus erythematosus. Nat Genet 2008;40(2):211-216. Part of the first generation of genome-wide association studies in SLE. [PubMed: 18204447]

18. Gateva V, Sandling JK, Hom G, et al. A large-scale replication study identifies TNIP1, PRDM1, $J A Z F 1, U H R F 1 B P 1$ and $I L 10$ as risk loci for systemic lupus erythematosus. Nat Genet 2009;41(11): 1228-1233. [PubMed: 19838195]

19••. Han JW, Zheng HF, Cui Y, et al. Genome-wide association study in a Chinese Han population identifies nine new susceptibility loci for systemic lupus erythematosus. Nat Genet 2009;41(11): 1234-1237. First large-scale genome-wide association study in an Asian population. [PubMed: 19838193]

20. Gaffney PM, Moser KL, Graham RR, Behrens TW. Recent advances in the genetics of systemic lupus erythematosus. Rheum Dis Clin North Am 2002;28(1):111-126. [PubMed: 11840693]

21. Schur PH. Genetics of systemic lupus erythematosus. Lupus 1995;4(6):425-437. [PubMed: 8749564]

22. Fernando MM, Stevens CR, Sabeti PC, et al. Identification of two independent risk factors for lupus within the MHC in United Kingdom families. PLoS Genet 2007;3(11):e192. [PubMed: 17997607]

23. Yao Z, Hartung K, Deicher HG, et al. DNA typing for HLA-DPB1-alleles in German patients with systemic lupus erythematosus using the polymerase chain reaction and DIG-ddUTP-labelled oligonucleotide probes. Members of SLE Study Group. Eur J Immunogenet 1993;20(4):259-266. [PubMed: 8399121]

24. Hartung K, Baur MP, Coldewey R, et al. Major histocompatibility complex haplotypes and complement C4 alleles in systemic lupus erythematosus. Results of a multicenter study. J Clin Invest 1992;90(4):1346-1351. [PubMed: 1401069]

25. Karassa FB, Trikalinos TA, Ioannidis JP. Role of the Fc $\gamma$ receptor IIa polymorphism in susceptibility to systemic lupus erythematosus and lupus nephritis: a meta-analysis. Arthritis Rheum 2002;46(6): 1563-1571. [PubMed: 12115187]

26. Salmon JE, Millard S, Schachter LA, et al. Fc $\gamma$ RIIA alleles are heritable risk factors for lupus nephritis in African Americans. J Clin Invest 1996;97(5):1348-1354. [PubMed: 8636449]

27. Lee YH, Rho YH, Choi SJ, et al. The PTPN22 C1858T functional polymorphism and autoimmune diseases - a meta-analysis. Rheumatology 2007;46(1):49-56. [PubMed: 16760194]

28. Kyogoku C, Langefeld CD, Ortmann WA, et al. Genetic association of the R620W polymorphism of protein tyrosine phosphatase PTPN22 with human SLE. Am J Hum Genet 2004;75(3):504-507. [PubMed: 15273934]

29. Graham RR, Kyogoku C, Sigurdsson S, et al. Three functional variants of IFN regulatory factor 5 (IRF5) define risk and protective haplotypes for human lupus. Proc Natl Acad Sci USA 2007;104 (16):6758-6763. [PubMed: 17412832]

30. Graham RR, Kozyrev SV, Baechler EC, et al. A common haplotype of interferon regulatory factor 5 (IRF5) regulates splicing and expression and is associated with increased risk of systemic lupus erythematosus. Nat Genet 2006;38(5):550-555. [PubMed: 16642019]

31. Sigurdsson S, Nordmark G, Goring HH, et al. Polymorphisms in the tyrosine kinase 2 and interferon regulatory factor 5 genes are associated with systemic lupus erythematosus. Am J Hum Genet 2005;76(3):528-537. [PubMed: 15657875] 
32. Remmers EF, Plenge RM, Lee AT, et al. STAT4 and the risk of rheumatoid arthritis and systemic lupus erythematosus. N Engl J Med 2007;357(10):977-986. [PubMed: 17804842]

33. Cunninghame Graham DS, Graham RR, Manku H, et al. Polymorphism at the TNF superfamily gene TNFSF4 confers susceptibility to systemic lupus erythematosus. Nat Genet 2008;40(1):83-89. [PubMed: 18059267]

34. Horton R, Wilming L, Rand V, et al. Gene map of the extended human MHC. Nat Rev 2004;5(12): 889-899.

35. Graham RR, Ortmann WA, Langefeld CD, et al. Visualizing human leukocyte antigen class II risk haplotypes in human systemic lupus erythematosus. Am J Hum Genet 2002;71(3):543-553. [PubMed: 12145745]

36. Graham RR, Ortmann W, Rodine P, et al. Specific combinations of HLA-DR2 and DR3 class II haplotypes contribute graded risk for disease susceptibility and autoantibodies in human SLE. Eur J Hum Genet 2007;15(8):823-830. [PubMed: 17406641]

37. Barcellos LF, May SL, Ramsay PP, et al. High-density SNP screening of the major histocompatibility complex in systemic lupus erythematosus demonstrates strong evidence for independent susceptibility regions. PLoS Genet 2009;5(10):e1000696. [PubMed: 19851445]

38. Crow MK. Collaboration, genetic associations, and lupus erythematosus. N Engl J Med 2008;358(9): 956-961. [PubMed: 18204099]

39. Stranger BE, Nica AC, Forrest MS, et al. Population genomics of human gene expression. Nat Genet 2007;39(10):1217-1224. [PubMed: 17873874]

40. Nath SK, Han S, Kim-Howard X, et al. A nonsynonymous functional variant in integrin- $\alpha(\mathrm{M})$ (encoded by ITGAM) is associated with systemic lupus erythematosus. Nat Genet 2008;40(2):152154. [PubMed: 18204448]

41. Plenge RM, Cotsapas C, Davies L, et al. Two independent alleles at 6q23 associated with risk of rheumatoid arthritis. Nat Genet 2007;39(12):1477-1482. [PubMed: 17982456]

42. Thomson W, Barton A, Ke X, et al. Rheumatoid arthritis association at 6q23. Nat Genet 2007;39(12): 1431-1433. [PubMed: 17982455]

43. Musone SL, Taylor KE, Lu TT, et al. Multiple polymorphisms in the TNFAIP3 region are independently associated with systemic lupus erythematosus. Nat Genet 2008;40:1062-1064. [PubMed: 19165919]

44. Jacob CO, Zhu J, Armstrong DL, et al. Identification of IRAKI as a risk gene with critical role in the pathogenesis of systemic lupus erythematosus. Proc Natl Acad Sci USA 2009;106(15):6256-6261. [PubMed: 19329491]

45. Jacob CO, Reiff A, Armstrong DL, et al. Identification of novel susceptibility genes in childhoodonset systemic lupus erythematosus using a uniquely designed candidate gene pathway platform. Arthritis Rheum 2007;56(12):4164-4173. [PubMed: 18050247]

46. Webb R, Wren JD, Jeffries M, et al. Variants within MECP2, a key transcription regulator, are associated with increased susceptibility to lupus and differential gene expression in patients with systemic lupus erythematosus. Arthritis Rheum 2009;60(4):1076-1084. [PubMed: 19333917]

47. Sawalha AH, Webb R, Han S, et al. Common variants within MECP2 confer risk of systemic lupus erythematosus. PloS One 2008;3(3):e1727. [PubMed: 18320046]

48. Oishi T, Iida A, Otsubo S, et al. A functional SNP in the NKX2.5-binding site of ITPR3 promoter is associated with susceptibility to systemic lupus erythematosus in Japanese population. J Hum Genet 2008;53(2):151-162. [PubMed: 18219441]

49. Baranzini SE. The genetics of autoimmune diseases: a networked perspective. Curr Opin Immunol 2009;21(6):596-605. [PubMed: 19896815]

50. Graham RR, Hom G, Ortmann W, Behrens TW. Review of recent genome-wide association scans in lupus. J Intern Med 2009;265(6):680-688. [PubMed: 19493061]

51. Ronnblom L, Alm GV, Eloranta ML. Type I interferon and lupus. Curr Opin Rheumatol 2009;21(5): 471-477. [PubMed: 19525849]

52. Ytterberg SR, Schnitzer TJ. Serum interferon levels in patients with systemic lupus erythematosus. Arthritis Rheum 1982;25(4):401-406. [PubMed: 6176248]

53. Hooks JJ, Moutsopoulos HM, Geis SA, Stahl NI, Decker JL, Notkins AL. Immune interferon in the circulation of patients with autoimmune disease. N Engl J Med 1979;301(1):5-8. [PubMed: 449915] 
54. Bengtsson AA, Sturfelt G, Truedsson L, et al. Activation of type I interferon system in systemic lupus erythematosus correlates with disease activity but not with antiretroviral antibodies. Lupus 2000;9 (9):664-671. [PubMed: 11199920]

55. Kirou KA, Lee C, George $\mathrm{S}$, et al. Coordinate overexpression of interferon- $\alpha$-induced genes in systemic lupus erythematosus. Arthritis Rheum 2004;50(12):3958-3967. [PubMed: 15593221]

56. Han GM, Chen SL, Shen N, Ye S, Bao CD, Gu YY. Analysis of gene expression profiles in human systemic lupus erythematosus using oligonucleotide microarray. Genes Immun 2003;4(3):177-186. [PubMed: 12700592]

57. Bennett L, Palucka AK, Arce E, et al. Interferon and granulopoiesis signatures in systemic lupus erythematosus blood. J Exp Med 2003;197(6):711-723. [PubMed: 12642603]

58. Baechler EC, Batliwalla FM, Karypis G, et al. Interferon-inducible gene expression signature in peripheral blood cells of patients with severe lupus. Proc Natl Acad Sci USA 2003;100(5):2610 2615. [PubMed: 12604793]

59. Crow MK, Kirou KA, Wohlgemuth J. Microarray analysis of interferon-regulated genes in SLE. Autoimmunity 2003;36(8):481-490. [PubMed: 14984025]

60. Bauer JW, Petri M, Batliwalla FM, et al. Interferon-regulated chemokines as biomarkers of systemic lupus erythematosus disease activity: a validation study. Arthritis Rheum 2009;60(10):3098-3107. [PubMed: 19790071]

61. Bauer JW, Baechler EC, Petri M, et al. Elevated serum levels of interferon-regulated chemokines are biomarkers for active human systemic lupus erythematosus. PLoS Med 2006;3(12):e491. [PubMed: 17177599]

62. Kirou KA, Lee C, George S, Louca K, Peterson MG, Crow MK. Activation of the interferon- $\alpha$ pathway identifies a subgroup of systemic lupus erythematosus patients with distinct serologic features and active disease. Arthritis Rheum 2005;52(5):1491-1503. [PubMed: 15880830]

63. Gota C, Calabrese L. Induction of clinical autoimmune disease by therapeutic interferon- $\alpha$. Autoimmunity 2003;36(8):511-518. [PubMed: 14984028]

64. Barton GM, Kagan JC, Medzhitov R. Intracellular localization of Toll-like receptor 9 prevents recognition of self DNA but facilitates access to viral DNA. Nat Immunol 2006;7(1):49-56. [PubMed: 16341217]

65. Lovgren T, Eloranta ML, Bave U, Alm GV, Ronnblom L. Induction of interferon- $\alpha$ production in plasmacytoid dendritic cells by immune complexes containing nucleic acid released by necrotic or late apoptotic cells and lupus IgG. Arthritis Rheum 2004;50(6):1861-1872. [PubMed: 15188363]

66. Bave U, Magnusson M, Eloranta ML, Perers A, Alm GV, Ronnblom L. Fc $\gamma$ RIIa is expressed on natural IFN- $\alpha$-producing cells (plasmacytoid dendritic cells) and is required for the IFN- $\alpha$ production induced by apoptotic cells combined with lupus IgG. J Immunol 2003;171(6):3296-3302. [PubMed: 12960360]

67. Magnusson M, Magnusson S, Vallin H, Ronnblom L, Alm GV. Importance of CpG dinucleotides in activation of natural IFN- $\alpha$-producing cells by a lupus-related oligodeoxynucleotide. Scand J Immunol 2001;54(6):543-550. [PubMed: 11902329]

68. Bave U, Vallin H, Alm GV, Ronnblom L. Activation of natural interferon- $\alpha$ producing cells by apoptotic U937 cells combined with lupus IgG and its regulation by cytokines. J Autoimmun 2001;17 (1):71-80. [PubMed: 11488639]

69. Bave U, Alm GV, Ronnblom L. The combination of apoptotic U937 cells and lupus IgG is a potent IFN- $\alpha$ inducer. J Immunol 2000;165(6):3519-3526. [PubMed: 10975873]

70. Vallin H, Perers A, Alm GV, Ronnblom L. Anti-double-stranded DNA antibodies and immunostimulatory plasmid DNA in combination mimic the endogenous IFN- $\alpha$ inducer in systemic lupus erythematosus. J Immunol 1999;163(11):6306-6313. [PubMed: 10570325]

71. Vallin H, Blomberg S, Alm GV, Cederblad B, Ronnblom L. Patients with systemic lupus erythematosus (SLE) have a circulating inducer of interferon- $\alpha$ (IFN- $\alpha$ ) production acting on leucocytes resembling immature dendritic cells. Clin Exp Immunol 1999;115(1):196-202. [PubMed: 9933442]

72. Means TK, Latz E, Hayashi F, Murali MR, Golenbock DT, Luster AD. Human lupus autoantibodyDNA complexes activate DCs through cooperation of CD32 and TLR9. J Clin Invest 2005;115(2): 407-417. [PubMed: 15668740] 
73. Savarese E, Chae OW, Trowitzsch S, et al. U1 small nuclear ribonucleoprotein immune complexes induce type I interferon in plasmacytoid dendritic cells through TLR7. Blood 2006;107(8):32293234. [PubMed: 16368889]

74. Lovgren T, Eloranta ML, Kastner B, Wahren-Herlenius M, Alm GV, Ronnblom L. Induction of interferon- $\alpha$ by immune complexes or liposomes containing systemic lupus erythematosus autoantigen- and Sjogren's syndrome autoantigen-associated RNA. Arthritis Rheum 2006;54(6): 1917-1927. [PubMed: 16729300]

75. Lau CM, Broughton C, Tabor AS, et al. RNA-associated autoantigens activate B cells by combined B cell antigen receptor/Toll-like receptor 7 engagement. J Exp Med 2005;202(9):1171-1177. [PubMed: 16260486]

76. Leadbetter EA, Rifkin IR, Hohlbaum AM, Beaudette BC, Shlomchik MJ, Marshak-Rothstein A. Chromatin-IgG complexes activate B cells by dual engagement of IgM and Toll-like receptors. Nature 2002;416(6881):603-607. [PubMed: 11948342]

77. Pisitkun P, Deane JA, Difilippantonio MJ, Tarasenko T, Satterthwaite AB, Bolland S. Autoreactive B cell responses to RNA-related antigens due to TLR7 gene duplication. Science 2006;312(5780): 1669-1672. [PubMed: 16709748]

78. Subramanian S, Tus K, Li QZ, et al. A Tlr7 translocation accelerates systemic autoimmunity in murine lupus. Proc Natl Acad Sci USA 2006;103(26):9970-9975. [PubMed: 16777955]

79. Deane JA, Pisitkun P, Barrett RS, et al. Control of Toll-like receptor 7 expression is essential to restrict autoimmunity and dendritic cell proliferation. Immunity 2007;27(5):801-810. [PubMed: 17997333]

80. Fairhurst AM, Hwang SH, Wang A, et al. Yaa autoimmune phenotypes are conferred by overexpression of TLR7. Eur J Immunol 2008;38(7):1971-1978. [PubMed: 18521959]

81. Santiago-Raber ML, Kikuchi S, Borel P, et al. Evidence for genes in addition to Tlr7 in the Yaa translocation linked with acceleration of systemic lupus erythematosus. J Immunol 2008;181(2): 1556-1562. [PubMed: 18606711]

82. Thibault DL, Graham KL, Lee LY, Balboni I, Hertzog PJ, Utz PJ. Type I interferon receptor controls B-cell expression of nucleic acid-sensing Toll-like receptors and autoantibody production in a murine model of lupus. Arthritis Res Ther 2009;11(4):R112. [PubMed: 19624844]

83. Thibault DL, Chu AD, Graham KL, et al. IRF9 and STAT1 are required for IgG autoantibody production and B cell expression of TLR7 in mice. J Clin Invest 2008;118(4):1417-1426. [PubMed: 18340381]

84. Bekeredjian-Ding IB, Wagner M, Hornung V, et al. Plasmacytoid dendritic cells control TLR7 sensitivity of naive B cells via type I IFN. J Immunol 2005;174(7):4043-4050. [PubMed: 15778362]

85. Jego G, Palucka AK, Blanck JP, Chalouni C, Pascual V, Banchereau J. Plasmacytoid dendritic cells induce plasma cell differentiation through type I interferon and interleukin 6. Immunity 2003;19(2): 225-234. [PubMed: 12932356]

86. Le Bon A, Schiavoni G, D’Agostino G, Gresser I, Belardelli F, Tough DF. Type I interferons potently enhance humoral immunity and can promote isotype switching by stimulating dendritic cells in vivo. Immunity 2001;14(4):461-470. [PubMed: 11336691]

87. Tamura T, Yanai H, Savitsky D, Taniguchi T. The IRF family transcription factors in immunity and oncogenesis. Ann Rev Immunol 2008;26:535-584. [PubMed: 18303999]

88. Honda K, Yanai H, Negishi H, et al. IRF-7 is the master regulator of type-I interferon-dependent immune responses. Nature 2005;434(7034):772-777. [PubMed: 15800576]

89. Colonna M, Trinchieri G, Liu YJ. Plasmacytoid dendritic cells in immunity. Nat Immunol 2004;5 (12):1219-1226. [PubMed: 15549123]

90. Yasuda K, Richez C, Maciaszek JW, et al. Murine dendritic cell type I IFN production induced by human IgG-RNA immune complexes is IFN regulatory factor (IRF) 5 and IRF7 dependent and is required for IL-6 production. J Immunol 2007;178(11):6876-6885. [PubMed: 17513736]

91. Takaoka A, Yanai H, Kondo S, et al. Integral role of IRF-5 in the gene induction programme activated by Toll-like receptors. Nature 2005;434(7030):243-249. [PubMed: 15665823]

92. Tsujimura H, Tamura T, Ozato K. Cutting edge: IFN consensus sequence binding protein/IFN regulatory factor 8 drives the development of type I IFN-producing plasmacytoid dendritic cells. J Immunol 2003;170(3):1131-1135. [PubMed: 12538667] 
93. Aliberti J, Schulz O, Pennington DJ, et al. Essential role for ICSBP in the in vivo development of murine CD8 $\alpha^{+}$dendritic cells. Blood 2003;101(1):305-310. [PubMed: 12393690]

94. Schiavoni G, Mattei F, Sestili P, et al. ICSBP is essential for the development of mouse type I interferon-producing cells and for the generation and activation of CD8 $\alpha^{+}$dendritic cells. J Exp Med 2002;196(11):1415-1425. [PubMed: 12461077]

95. Zhao J, Kong HJ, Li H, et al. IRF-8/interferon (IFN) consensus sequence-binding protein is involved in Toll-like receptor (TLR) signaling and contributes to the cross-talk between TLR and IFN- $\gamma$ signaling pathways. J Biol Chem 2006;281(15):10073-10080. [PubMed: 16484229]

96. Tsujimura H, Tamura T, Kong HJ, et al. Toll-like receptor 9 signaling activates NF- $\mathrm{B}$ through IFN regulatory factor-8/IFN consensus sequence binding protein in dendritic cells. J Immunol 2004;172 (11):6820-6827. [PubMed: 15153500]

97. Gottipati S, Rao NL, Fung-Leung WP. IRAK1: a critical signaling mediator of innate immunity. Cell Signal 2008;20(2):269-276. [PubMed: 17890055]

98. Neumann D, Kollewe C, Resch K, Martin MU. The death domain of IRAK-1: an oligomerization domain mediating interactions with MyD88, Tollip, IRAK-1, and IRAK-4. Biochem Biophys Res Commun 2007;354(4):1089-1094. [PubMed: 17276401]

99. Cao Z, Xiong J, Takeuchi M, Kurama T, Goeddel DV. TRAF6 is a signal transducer for interleukin-1. Nature 1996;383(6599):443-446. [PubMed: 8837778]

100. Uematsu S, Sato S, Yamamoto M, et al. Interleukin-1 receptor-associated kinase-1 plays an essential role for Toll-like receptor (TLR)7- and TLR9-mediated interferon- $\alpha$ induction. J Exp Med 2005;201 (6):915-923. [PubMed: 15767370]

101. Kanakaraj P, Schafer PH, Cavender DE, et al. Interleukin (IL)-1 receptor-associated kinase (IRAK) requirement for optimal induction of multiple IL-1 signaling pathways and IL-6 production. J Exp Med 1998;187(12):2073-2079. [PubMed: 9625767]

102. Kawagoe T, Sato S, Matsushita K, et al. Sequential control of Toll-like receptor-dependent responses by IRAK1 and IRAK2. Nat Immunol 2008;9(6):684-691. [PubMed: 18438411]

103. Bhoj VG, Chen ZJ. Ubiquitylation in innate and adaptive immunity. Nature 2009;458(7237):430437. [PubMed: 19325622]

104. Oshima S, Turer EE, Callahan JA, et al. ABIN-1 is a ubiquitin sensor that restricts cell death and sustains embryonic development. Nature 2009;457(7231):906-909. [PubMed: 19060883]

105. Mauro C, Pacifico F, Lavorgna A, et al. ABIN-1 binds to NEMO/IKK $\gamma$ and co-operates with A20 in inhibiting NF- $\kappa$ B. J Biol Chem 2006;281(27):18482-18488. [PubMed: 16684768]

106. Heyninck K, De Valck D, Vanden Berghe W, et al. The zinc finger protein A20 inhibits TNF-induced $\mathrm{NF}-\kappa \mathrm{B}-$ dependent gene expression by interfering with an RIP- or TRAF2-mediated transactivation signal and directly binds to a novel NF-אB-inhibiting protein ABIN. J Cell Biol 1999;145(7):14711482. [PubMed: 10385526]

107. Deng L, Wang C, Spencer E, et al. Activation of the I $\mathrm{KB}$ kinase complex by TRAF6 requires a dimeric ubiquitin-conjugating enzyme complex and a unique polyubiquitin chain. Cell 2000;103 (2):351-361. [PubMed: 11057907]

108. Geetha T, Jiang J, Wooten MW. Lysine 63 polyubiquitination of the nerve growth factor receptor TrkA directs internalization and signaling. Mol Cell 2005;20(2):301-312. [PubMed: 16246731]

109. Balkhi MY, Fitzgerald KA, Pitha PM. Functional regulation of MyD88-activated interferon regulatory factor 5 by K63-linked polyubiquitination. Mol Cell Biol 2008;28(24):7296-7308. [PubMed: 18824541]

110. Kawai T, Sato S, Ishii KJ, et al. Interferon- $\alpha$ induction through Toll-like receptors involves a direct interaction of IRF7 with MyD88 and TRAF6. Nat Immunol 2004;5(10):1061-1068. [PubMed: 15361868]

111. Lee HK, Lund JM, Ramanathan B, Mizushima N, Iwasaki A. Autophagy-dependent viral recognition by plasmacytoid dendritic cells. Science 2007;315(5817):1398-1401. [PubMed: 17272685]

112. Honda K, Ohba Y, Yanai H, et al. Spatiotemporal regulation of MyD88-IRF-7 signalling for robust type-I interferon induction. Nature 2005;434(7036):1035-1040. [PubMed: 15815647]

113. Rock J, Schneider E, Grun JR, et al. CD303 (BDCA-2) signals in plasmacytoid dendritic cells via a BCR-like signalosome involving Syk, Slp65 and PLC $\gamma 2$. Eur J Immunol 2007;37(12):3564-3575. [PubMed: 18022864] 
114. Kariuki SN, Kirou KA, MacDermott EJ, Barillas-Arias L, Crow MK, Niewold TB. Cutting edge: autoimmune disease risk variant of STAT4 confers increased sensitivity to IFN- $\alpha$ in lupus patients in vivo. J Immunol 2009;182(1):34-38. [PubMed: 19109131]

115. Georgopoulos K, Bigby M, Wang JH, et al. The Ikaros gene is required for the development of all lymphoid lineages. Cell 1994;79(1):143-156. [PubMed: 7923373]

116. Yap WH, Yeoh E, Tay A, Brenner S, Venkatesh B. STAT4 is a target of the hematopoietic zincfinger transcription factor Ikaros in T cells. FEBS Lett 2005;579(20):4470-4478. [PubMed: 16081070]

117. Gyory I, Wu J, Fejer G, Seto E, Wright KL. PRDI-BF1 recruits the histone H3 methyltransferase G9a in transcriptional silencing. Nat Immunol 2004;5(3):299-308. [PubMed: 14985713]

118. Keller AD, Maniatis T. Only two of the five zinc fingers of the eukaryotic transcriptional repressor PRDI-BF1 are required for sequence-specific DNA binding. Mol Cell Biol 1992;12(5):1940-1949. [PubMed: 1569931]

119. Keller AD, Maniatis T. Identification and characterization of a novel repressor of $\beta$-interferon gene expression. Genes Develop 1991;5(5):868-879. [PubMed: 1851123]

120. Calame KL, Lin KI, Tunyaplin C. Regulatory mechanisms that determine the development and function of plasma cells. Ann Rev Immunol 2003;21:205-230. [PubMed: 12524387]

121. Rutherford MN, Kumar A, Haque SJ, Ghysdael J, Williams BR. Specific binding of the ETS-domain protein to the interferon-stimulated response element. J Interferon Cytokine Res 1997;17(1):1-10. [PubMed: 9041465]

122. Gallant S, Gilkeson G. ETS transcription factors and regulation of immunity. Arch Immunol Ther Exp (Warsz) 2006;54(3):149-163. [PubMed: 16652219]

123. Liou LY, Blasius AL, Welch MJ, Colonna M, Oldstone MB, Zuniga EI. In vivo conversion of BM plasmacytoid DC into CD11 $\mathrm{b}^{+}$conventional DC during virus infection. Eur J Immunol 2008;38 (12):3388-3394. [PubMed: 18979509]

124. Crotzer VL, Blum JS. Autophagy and its role in MHC-mediated antigen presentation. J Immunol 2009;182(6):3335-3341. [PubMed: 19265109]

125. Zheng Y, Liu H, Coughlin J, Zheng J, Li L, Stone JC. Phosphorylation of RasGRP3 on threonine 133 provides a mechanistic link between PKC and Ras signaling systems in B cells. Blood 2005;105 (9):3648-3654. [PubMed: 15657177]

126. Yokoyama K, Su Ih IH, Tezuka T, et al. BANK regulates BCR-induced calcium mobilization by promoting tyrosine phosphorylation of IP(3) receptor. EMBO J 2002;21(1-2):83-92. [PubMed: 11782428]

127. Croft M, So T, Duan W, Soroosh P. The significance of OX40 and OX40L to T-cell biology and immune disease. Immunol Rev 2009;229(1):173-191. [PubMed: 19426222]

128. Nakajima T, Fujino S, Nakanishi G, Kim YS, Jetten AM. TIP27: a novel repressor of the nuclear orphan receptor TAK1/TR4. Nucleic Acids Res 2004;32(14):4194-4204. [PubMed: 15302918]

129. Zeggini E, Scott LJ, Saxena R, et al. Meta-analysis of genome-wide association data and large-scale replication identifies additional susceptibility loci for type 2 diabetes. Nat Genet 2008;40(5):638645. [PubMed: 18372903]

130. Johansson A, Marroni F, Hayward C, et al. Common variants in the JAZF1 gene associated with height identified by linkage and genome-wide association analysis. Hum Mol Genet 2009;18(2): 373-380. [PubMed: 18952825]

131. Kaplan J, De Domenico I, Ward DM. Chediak-Higashi syndrome. Curr Opin Hematol 2008;15(1): 22-29. [PubMed: 18043242]

132. Zhernakova A, van Diemen CC, Wijmenga C. Detecting shared pathogenesis from the shared genetics of immune-related diseases. Nat Rev 2009;10(1):43-55.

133. Gregersen PK, Olsson LM. Recent advances in the genetics of autoimmune disease. Ann Rev Immunol 2009;27:363-391. [PubMed: 19302045]

134. Michou L, Rat AC, Lasbleiz S, Bardin T, Cornelis F. Prevalence and distribution of autoimmune diseases in 368 rheumatoid arthritis families. J Rheumatol 2008;35(5):790-796. [PubMed: 18381797]

135. Somers EC, Thomas SL, Smeeth L, Hall AJ. Autoimmune diseases co-occurring within individuals and within families: a systematic review. Epidemiology 2006;17(2):202-217. [PubMed: 16477262] 
136. Kero J, Gissler M, Hemminki E, Isolauri E. Could TH1 and TH2 diseases coexist? Evaluation of asthma incidence in children with coeliac disease, type 1 diabetes, or rheumatoid arthritis: a register study. J Allergy Clin Immunol 2001;108(5):781-783. [PubMed: 11692104]

137. Criswell LA, Pfeiffer KA, Lum RF, et al. Analysis of families in the multiple autoimmune disease genetics consortium (MADGC) collection: the PTPN22 620W allele associates with multiple autoimmune phenotypes. Am J Hum Genet 2005;76(4):561-571. [PubMed: 15719322]

138. Zoledziewska M, Costa G, Pitzalis M, et al. Variation within the CLEC16A gene shows consistent disease association with both multiple sclerosis and type 1 diabetes in Sardinia. Genes Immun 2009;10(1):15-17. [PubMed: 18946483]

139. Awata T, Kawasaki E, Tanaka S, et al. Association of type 1 diabetes with two loci on 12q13 and 16 p13 and the influence coexisting thyroid autoimmunity in Japanese. J Clin Endocrinol Metab 2009;94(1):231-235. [PubMed: 18940880]

140. Skinningsrud B, Husebye ES, Pearce SH, et al. Polymorphisms in CLEC16A and CIITA at 16p13 are associated with primary adrenal insufficiency. J Clin Endocrinol Metab 2008;93(9):3310-3317. [PubMed: 18593762]

141. Franke A, Fischer A, Nothnagel M, et al. Genome-wide association analysis in sarcoidosis and Crohn's disease unravels a common susceptibility locus on 10p12.2. Gastroenterology 2008;135 (4):1207-1215. [PubMed: 18723019]

142. Cloutier JF, Veillette A. Association of inhibitory tyrosine protein kinase p50csk with protein tyrosine phosphatase PEP in T cells and other hemopoietic cells. EMBO J 1996;15(18):4909-4918. [PubMed: 8890164]

143. Bottini N, Musumeci L, Alonso A, et al. A functional variant of lymphoid tyrosine phosphatase is associated with type I diabetes. Nat Genet 2004;36(4):337-338. [PubMed: 15004560]

144. Begovich AB, Carlton VE, Honigberg LA, et al. A missense single-nucleotide polymorphism in a gene encoding a protein tyrosine phosphatase (PTPN22) is associated with rheumatoid arthritis. Am J Hum Genet 2004;75(2):330-337. [PubMed: 15208781]

145. Arechiga AF, Habib T, He Y, et al. Cutting edge: the PTPN22 allelic variant associated with autoimmunity impairs B cell signaling. J Immunol 2009;182(6):3343-3347. [PubMed: 19265110]

146. Rieck M, Arechiga A, Onengut-Gumuscu S, Greenbaum C, Concannon P, Buckner JH. Genetic variation in PTPN22 corresponds to altered function of T and B lymphocytes. J Immunol 2007;179 (7):4704-4710. [PubMed: 17878369]

147. Vang T, Congia M, Macis MD, et al. Autoimmune-associated lymphoid tyrosine phosphatase is a gain-of-function variant. Nat Genet 2005;37(12):1317-1319. [PubMed: 16273109]

148. Zikherman J, Hermiston M, Steiner D, Hasegawa K, Chan A, Weiss A. PTPN22 deficiency cooperates with the CD45 E613R allele to break tolerance on a non-autoimmune background. J Immunol 2009;182(7):4093-4106. [PubMed: 19299707]

149. Velaga MR, Wilson V, Jennings CE, et al. The codon 620 tryptophan allele of the lymphoid tyrosine phosphatase $(L Y P)$ gene is a major determinant of Graves' disease. J Clin Endocrinol Metab 2004;89 (11):5862-5865. [PubMed: 15531553]

150. Barrett JC, Hansoul S, Nicolae DL, et al. Genome-wide association defines more than 30 distinct susceptibility loci for Crohn's disease. Nat Genet 2008;40(8):955-962. [PubMed: 18587394]

151. Rueda B, Nunez C, Orozco G, et al. C1858T functional variant of PTPN22 gene is not associated with celiac disease genetic predisposition. Hum Immunol 2005;66(7):848-852. [PubMed: 16112033]

152. Orru V, Tsai SJ, Rueda B, et al. A loss-of-function variant of PTPN22 is associated with reduced risk of systemic lupus erythematosus. Hum Mol Genet 2009;18(3):569-579. [PubMed: 18981062]

153. Velazquez L, Cheng AM, Fleming HE, et al. Cytokine signaling and hematopoietic homeostasis are disrupted in Lnk-deficient mice. J Exp Med 2002;195(12):1599-1611. [PubMed: 12070287]

154. Yokouchi M, Suzuki R, Masuhara M, Komiya S, Inoue A, Yoshimura A. Cloning and characterization of APS, an adaptor molecule containing PH and $\mathrm{SH} 2$ domains that is tyrosine phosphorylated upon B-cell receptor stimulation. Oncogene 1997;15(1):7-15. [PubMed: 9233773]

155. Huang X, Li Y, Tanaka K, Moore KG, Hayashi JI. Cloning and characterization of Lnk, a signal transduction protein that links $\mathrm{T}$-cell receptor activation signal to phospholipase $\mathrm{C} \gamma 1$, Grb2, and 
phosphatidylinositol 3-kinase. Proc Natl Acad Sci USA 1995;92(25):11618-11622. [PubMed: 8524815]

156. Li Y, He X, Schembri-King J, Jakes S, Hayashi J. Cloning and characterization of human Lnk, an adaptor protein with pleckstrin homology and Src homology 2 domains that can inhibit $\mathrm{T}$ cell activation. J Immunol 2000;164(10):5199-5206. [PubMed: 10799879]

157. Smyth DJ, Plagnol V, Walker NM, et al. Shared and distinct genetic variants in type 1 diabetes and celiac disease. N Engl J Med 2008;359(26):2767-2777. [PubMed: 19073967]

158. Hunt KA, Zhernakova A, Turner G, et al. Newly identified genetic risk variants for celiac disease related to the immune response. Nat Genet 2008;40(4):395-402. [PubMed: 18311140]

159. van Heel DA, Franke L, Hunt KA, et al. A genome-wide association study for celiac disease identifies risk variants in the region harboring IL2 and IL21. Nat Genet 2007;39(7):827-829. [PubMed: 17558408]

160. Todd JA, Walker NM, Cooper JD, et al. Robust associations of four new chromosome regions from genome-wide analyses of type 1 diabetes. Nat Genet 2007;39(7):857-864. [PubMed: 17554260]

161. Dymecki SM, Zwollo P, Zeller K, Kuhajda FP, Desiderio SV. Structure and developmental regulation of the B-lymphoid tyrosine kinase gene blk. J Biol Chem 1992;267(7):4815-4823. [PubMed: 1537861]

162. Gregersen PK, Amos CI, Lee AT, et al. REL, encoding a member of the NF- $\kappa B$ family of transcription factors, is a newly defined risk locus for rheumatoid arthritis. Nat Genet 2009;41(7):820-823. [PubMed: 19503088]

163. Yin H, Borghi MO, Delgado-Vega AM, Tincani A, Meroni PL, Alarcon-Riquelme ME. Association of STAT4 and BLK, but not BANK1 or IRF5, with primary antiphospholipid syndrome. Arthritis Rheum 2009;60(8):2468-2471. [PubMed: 19644876]

164. Texido G, Su IH, Mecklenbrauker I, et al. The B-cell-specific Src-family kinase Blk is dispensable for B-cell development and activation. Mol Cell Biol 2000;20(4):1227-1233. [PubMed: 10648608]

165. Steinman L. A brief history of $\mathrm{T}(\mathrm{H}) 17$, the first major revision in the $\mathrm{T}(\mathrm{H}) 1 / \mathrm{T}(\mathrm{H}) 2$ hypothesis of $\mathrm{T}$ cell-mediated tissue damage. Nat Med 2007;13(2):139-145. [PubMed: 17290272]

166. Mosmann TR, Cherwinski H, Bond MW, Giedlin MA, Coffman RL. Two types of murine helper T cell clone. I. Definition according to profiles of lymphokine activities and secreted proteins. J Immunol 1986;136(7):2348-2357. [PubMed: 2419430]

167. Coffman RL, Carty J. A T cell activity that enhances polyclonal IgE production and its inhibition by interferon- $\gamma$. J Immunol 1986;136(3):949-954. [PubMed: 2934482]

168. Coffman RL. Origins of the $\mathrm{T}(\mathrm{H}) 1-\mathrm{T}(\mathrm{H}) 2$ model: a personal perspective. Nat Immunol 2006;7(6): 539-541. [PubMed: 16715060]

169. Kim HS, Kim I, Kim JO, Bae JS, Shin HD, Bae SC. No association between interleukin 23 receptor gene polymorphisms and systemic lupus erythematosus. Rheumatol Int 2009;30(1):33-38.

170. Sanchez E, Rueda B, Callejas JL, et al. Analysis of interleukin-23 receptor (IL23R) gene polymorphisms in systemic lupus erythematosus. Tissue Antigens 2007;70(3):233-237. [PubMed: 17661912]

171. Fisher SA, Tremelling M, Anderson CA, et al. Genetic determinants of ulcerative colitis include the ECM1 locus and five loci implicated in Crohn's disease. Nat Genet 2008;40(6):710-712. [PubMed: 18438406]

172. Nair RP, Duffin KC, Helms C, et al. Genome-wide scan reveals association of psoriasis with IL-23 and NF- $\kappa B$ pathways. Nat Genet 2009;41(2):199-204. [PubMed: 19169254]

173. Franke A, Balschun T, Karlsen TH, et al. Sequence variants in IL10, ARPC2 and multiple other loci contribute to ulcerative colitis susceptibility. Nat Genet 2008;40(11):1319-1323. [PubMed: 18836448]

174. Barrett JC, Clayton DG, Concannon P, et al. Genome-wide association study and meta-analysis find that over 40 loci affect risk of type 1 diabetes. Nat Genet 2009;41:703-707.

175. O'Garra A, Murphy KM. From IL-10 to IL-12: how pathogens and their products stimulate APCs to induce T(H)1 development. Nat Immunol 2009;10(9):929-932. [PubMed: 19692989]

176. De Jager PL, Jia X, Wang J, et al. Meta-analysis of genome scans and replication identify CD6, IRF8 and TNFRSF1A as new multiple sclerosis susceptibility loci. Nat Genet 2009;41(7):776-782. [PubMed: 19525953] 
177. Ban M, Goris A, Lorentzen AR, et al. Replication analysis identifies TYK2 as a multiple sclerosis susceptibility factor. Eur J Hum Genet 2009;17(10):1309-1313. [PubMed: 19293837]

178. Smyth DJ, Cooper JD, Bailey R, et al. A genome-wide association study of nonsynonymous SNPs identifies a type 1 diabetes locus in the interferon-induced helicase (IFIH1) region. Nat Genet 2006;38(6):617-619. [PubMed: 16699517]

179. Sutherland A, Davies J, Owen CJ, et al. Genomic polymorphism at the interferon-induced helicase (IFIH1) locus contributes to Graves' disease susceptibility. J Clin Endocrinol Metab 2007;92(8): 3338-3341. [PubMed: 17535987]

180. Andrejeva J, Childs KS, Young DF, et al. The V proteins of paramyxoviruses bind the IFN-inducible RNA helicase, mda-5, and inhibit its activation of the IFN- $\beta$ promoter. Proc Natl Acad Sci USA 2004;101(49):17264-17269. [PubMed: 15563593]

181. Stetson DB. Connections between antiviral defense and autoimmunity. Curr Opin Immunol 2009;21 (3):244-250. [PubMed: 19497722]

182. Lokki ML, Koskimies SA. Allelic differences in hemolytic activity and protein concentration of BF molecules are found in association with particular HLA haplotypes. Immunogenetics 1991;34(4): 242-246. [PubMed: 1916952]

183. Gold B, Merriam JE, Zernant J, et al. Variation in factor B $(B F)$ and complement component 2 (C2) genes is associated with age-related macular degeneration. Nat Genet 2006;38(4):458-462. [PubMed: 16518403]

184. Nitsch D, Douglas I, Smeeth L, Fletcher A. Age-related macular degeneration and complement activation-related diseases: a population-based case-control study. Ophthalmology 2008;115(11): 1904-1910. [PubMed: 18801575]

185. Renner P, Roger T, Calandra T. Macrophage migration inhibitory factor: gene polymorphisms and susceptibility to inflammatory diseases. Clin Infect Dis 2005;41(Suppl 7):S513-S519. [PubMed: 16237655]

186. Sanchez E, Gomez LM, Lopez-Nevot MA, et al. Evidence of association of macrophage migration inhibitory factor gene polymorphisms with systemic lupus erythematosus. Genes Immun 2006;7 (5):433-436. [PubMed: 16724072]

187. Radstake TR, Sweep FC, Welsing P, et al. Correlation of rheumatoid arthritis severity with the genetic functional variants and circulating levels of macrophage migration inhibitory factor. Arthritis Rheum 2005;52(10):3020-3029. [PubMed: 16200611]

188. Dambacher J, Staudinger T, Seiderer J, et al. Macrophage migration inhibitory factor (MIF) -173G/ $\mathrm{C}$ promoter polymorphism influences upper gastrointestinal tract involvement and disease activity in patients with Crohn's disease. Inflam Bowel Dis 2007;13(1):71-82.

189. Donn RP, Plant D, Jury F, et al. Macrophage migration inhibitory factor gene polymorphism is associated with psoriasis. J Invest Dermatol 2004;123(3):484-487. [PubMed: 15304087]

190. Nunez C, Rueda B, Martinez A, et al. Involvement of macrophage migration inhibitory factor gene in celiac disease susceptibility. Genes Immun 2007;8(2):168-170. [PubMed: 17215861]

191. Icen M, Nicola PJ, Maradit-Kremers H, et al. Systemic lupus erythematosus features in rheumatoid arthritis and their effect on overall mortality. J Rheumatol 2009;36(1):50-57. [PubMed: 19004043]

192. Raychaudhuri S, Thomson BP, Remmers EF, et al. Genetic variants at CD28, PRDM1 and CD2/ CD58 are associated with rheumatoid arthritis risk. Nat Genet 2009;41(12):1313-1318. [PubMed: 19898481]

193. Dieguez-Gonzalez R, Calaza M, Perez-Pampin E, et al. Association of interferon regulatory factor 5 haplotypes, similar to that found in systemic lupus erythematosus, in a large subgroup of patients with rheumatoid arthritis. Arthritis Rheum 2008;58(5):1264-1274. [PubMed: 18438842]

194. Sigurdsson S, Padyukov L, Kurreeman FA, et al. Association of a haplotype in the promoter region of the interferon regulatory factor 5 gene with rheumatoid arthritis. Arthritis Rheum 2007;56(7): 2202-2210. [PubMed: 17599733]

195. Garnier S, Dieude P, Michou L, et al. IRF5 rs2004640-T allele, the new genetic factor for systemic lupus erythematosus, is not associated with rheumatoid arthritis. Ann Rheum Dis 2007;66(6):828831. [PubMed: 17158136]

196. Rueda B, Reddy MV, Gonzalez-Gay MA, et al. Analysis of IRF5 gene functional polymorphisms in rheumatoid arthritis. Arthritis Rheum 2006;54(12):3815-3819. [PubMed: 17133578] 
197. Suarez-Gestal M, Calaza M, Dieguez-Gonzalez R, et al. Rheumatoid arthritis does not share most of the newly identified systemic lupus erythematosus genetic factors. Arthritis Rheum 2009;60(9): 2558-2564. [PubMed: 19714582]

198. Fung EY, Smyth DJ, Howson JM, et al. Analysis of 17 autoimmune disease-associated variants in type 1 diabetes identifies 6q23/TNFAIP3 as a susceptibility locus. Genes Immun 2009;10(2):188191. [PubMed: 19110536]

199. Trynka G, Zhernakova A, Romanos J, et al. Coeliac disease-associated risk variants in TNFAIP3 and REL implicate altered NF- $\kappa$ B signalling. Gut 2009;58(8):1078-1083. [PubMed: 19240061]

200. Genome-wide association study of 14,000 cases of seven common diseases and 3,000 shared controls. Nature 2007;447(7145):661-678. [PubMed: 17554300]

201. Kato M, Sanada M, Kato I, et al. Frequent inactivation of A20 in B-cell lymphomas. Nature 2009;459 (7247):712-716. [PubMed: 19412163]

202. Karin M. Nuclear factor- $\kappa B$ in cancer development and progression. Nature 2006;441(7092):431436. [PubMed: 16724054]

203. Vereecke L, Beyaert R, van Loo G. The ubiquitin-editing enzyme A20 (TNFAIP3) is a central regulator of immunopathology. Trends Immunol 2009;30(8):383-391. [PubMed: 19643665]

204. Wertz IE, O'Rourke KM, Zhou H, et al. De-ubiquitination and ubiquitin ligase domains of A20 downregulate NF-кB signalling. Nature 2004;430(7000):694-699. [PubMed: 15258597]

205. Boone DL, Turer EE, Lee EG, et al. The ubiquitin-modifying enzyme A20 is required for termination of Toll-like receptor responses. Nat Immunol 2004;5(10):1052-1060. [PubMed: 15334086]

206. Heyninck K, Beyaert R. The cytokine-inducible zinc finger protein A20 inhibits IL-1-induced NF$\kappa \mathrm{B}$ activation at the level of TRAF6. FEBS Lett 1999;442(2-3):147-150. [PubMed: 9928991]

207. Opipari AW Jr, Hu HM, Yabkowitz R, Dixit VM. The A20 zinc finger protein protects cells from tumor necrosis factor cytotoxicity. J Biol Chem 1992;267(18):12424-12427. [PubMed: 1618749]

208. Lee EG, Boone DL, Chai S, et al. Failure to regulate TNF-induced NF- $\kappa B$ and cell death responses in A20-deficient mice. Science 2000;289(5488):2350-2354. [PubMed: 11009421]

209. Elliott MJ, Maini RN, Feldmann M, et al. Randomised double-blind comparison of chimeric monoclonal antibody to tumour necrosis factor $\alpha(\mathrm{cA} 2)$ versus placebo in rheumatoid arthritis. Lancet 1994;344(8930):1105-1110. [PubMed: 7934491]

210. Manolio TA, Collins FS, Cox NJ, et al. Finding the missing heritability of complex diseases. Nature 2009;461(7265):747-753. [PubMed: 19812666]

211. Mardis ER. The impact of next-generation sequencing technology on genetics. Trends Genet 2008;24(3):133-141. [PubMed: 18262675]

212••. Dendrou CA, Plagnol V, Fung E, et al. Cell-specific protein phenotypes for the autoimmune locus IL2RA using a genotype-selectable human bioresource. Nat Genet 2009;41(9):1011-1015. Largescale study into biological mechanisms that highlights the challenges in understanding the correlation of genotype and phenotype in common diseases. [PubMed: 19701192]

\section{Website}

301. 1000 genomes. Pilot 2 and Pilot 3 SNP calls updated www.1000genomes.org

Expert Rev Clin Immunol. Author manuscript; available in PMC 2011 March 1. 


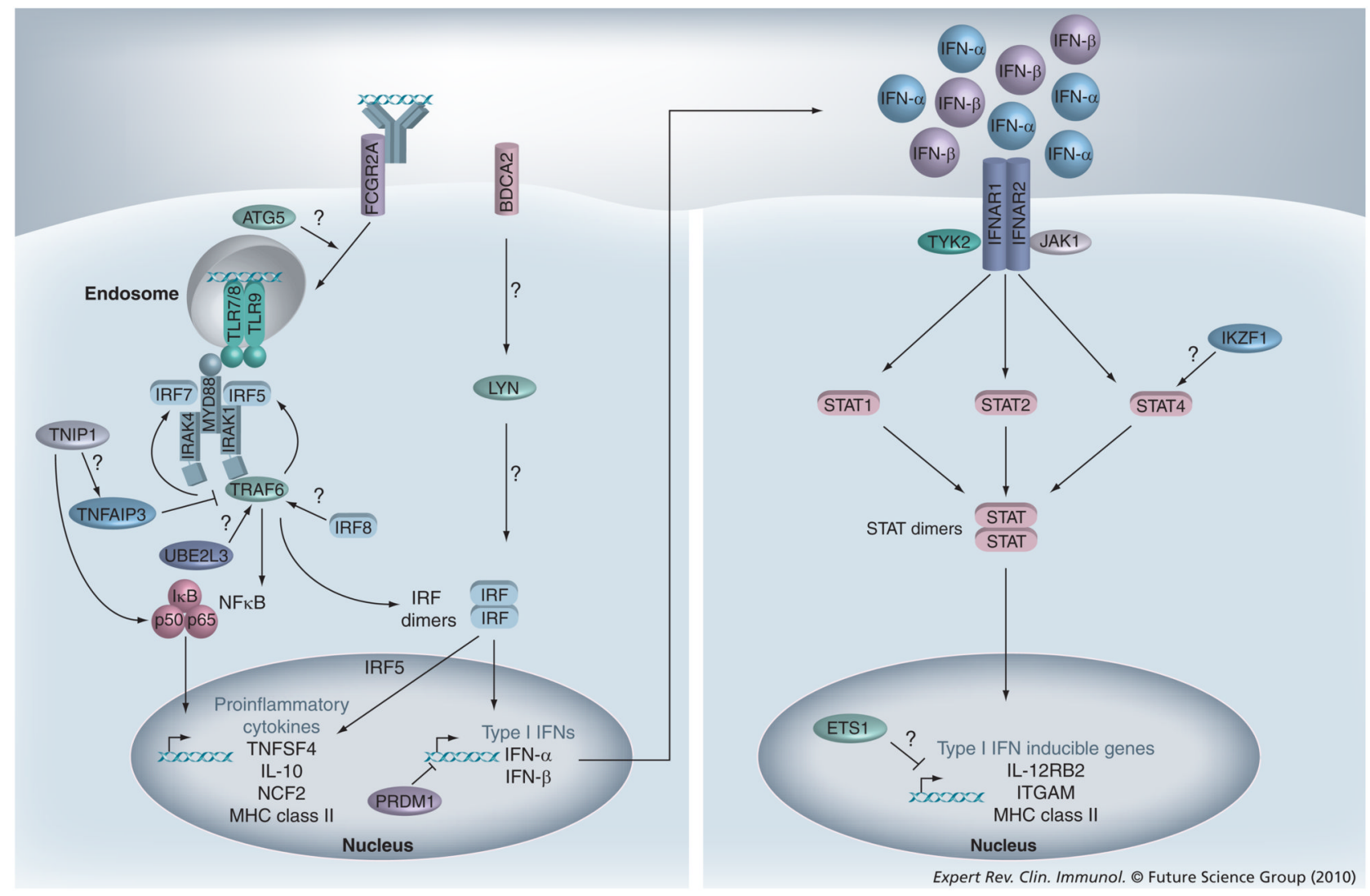

Figure 1. Many SLE risk loci function in the Toll-like receptor/IFN-I signaling pathway

Nucleic acid-sensing TLRs, which include TLR-3, -7, -8 and -9, are localized to endosomal compartments. SLE immune complexes that contain nucleic acids are bound by FCGR2A on the surface of dendritic cells and are subsequently internalized where they gain access to the endosome and activate TLRs. TLR7, TLR8 and TLR9 signal through the adaptor protein MyD88, the kinases IRAK1 and IRAK4, and the E3 ubiquitin ligase TRAF6. Upon stimulation, the IRF family members IRF5 and IRF7 are phosphorylated, dimerize and translocate to the nucleus where they induce transcription of IFN-I. IRF5 is also critical for the induction of proinflammatory cytokines in response to TLR stimulation. TLR signaling activates the NF$\kappa \mathrm{B}$ transcription factor, which promotes the induction of many proinflammatory cytokines and other inflammatory genes. TNFAIP3 is a negative regulator of TRAF6 and inhibits the activation of NFKB. IFN-Is, which include many subtypes of IFN- $\alpha$ and a single subtype of IFN- $\beta$, bind to their receptor, which is composed of two chains, IFNAR1 and IFNAR2.

Signaling through the receptor results in the activation of receptor-associated Janus kinases, JAK1 and TYK2, which in turn promote the phosphorylation of the STAT family members STAT1, STAT2 and STAT4. Upon activation, STAT proteins dimerize, translocate to the nucleus and induce the expression of IFN-I-inducible genes. In many cases, the evidence supporting certain functions is preliminary or inconclusive, as indicated by the '?' and as described in the main text.

ATG: Autophagy-specific gene; BDCA: Blood dendritic cell antigen; ETS1: v-ets erythroblastosis virus E26 oncogene homolog 1; FCGR2A: Fc fragment of IgG receptor IIa; IFN-I: Type I interferon; IFNAR: IFN ( $\alpha$ and $\beta$ ) receptor; IKZF1: Ikaros family zinc finger 1; IRAK: IL-1 receptor-associated kinase; IRF: Interferon regulatory factor; ITGAM: Integrin $\alpha$ M; JAK: Janus kinase; LYN: v-yes-1 Yamaguchi sarcoma viral-related oncogene homolog; MyD88: Myeloid differentiation primary response gene 88; NCF2: Neutrophil cytosolic factor 
2; PRDM1: PR domain containing 1; STAT: Signal transducer and activator of transcription; TLR: Toll-like receptor; TNFAIP: TNF- $\alpha$-induced protein; TNFSF4: TNF ligand superfamily 4; TRAF6: TNF receptor-associated factor 6; TYK2: Tyrosine kinase 2; UBE2L3: Ubiquitinconjugating enzyme E2L3. 


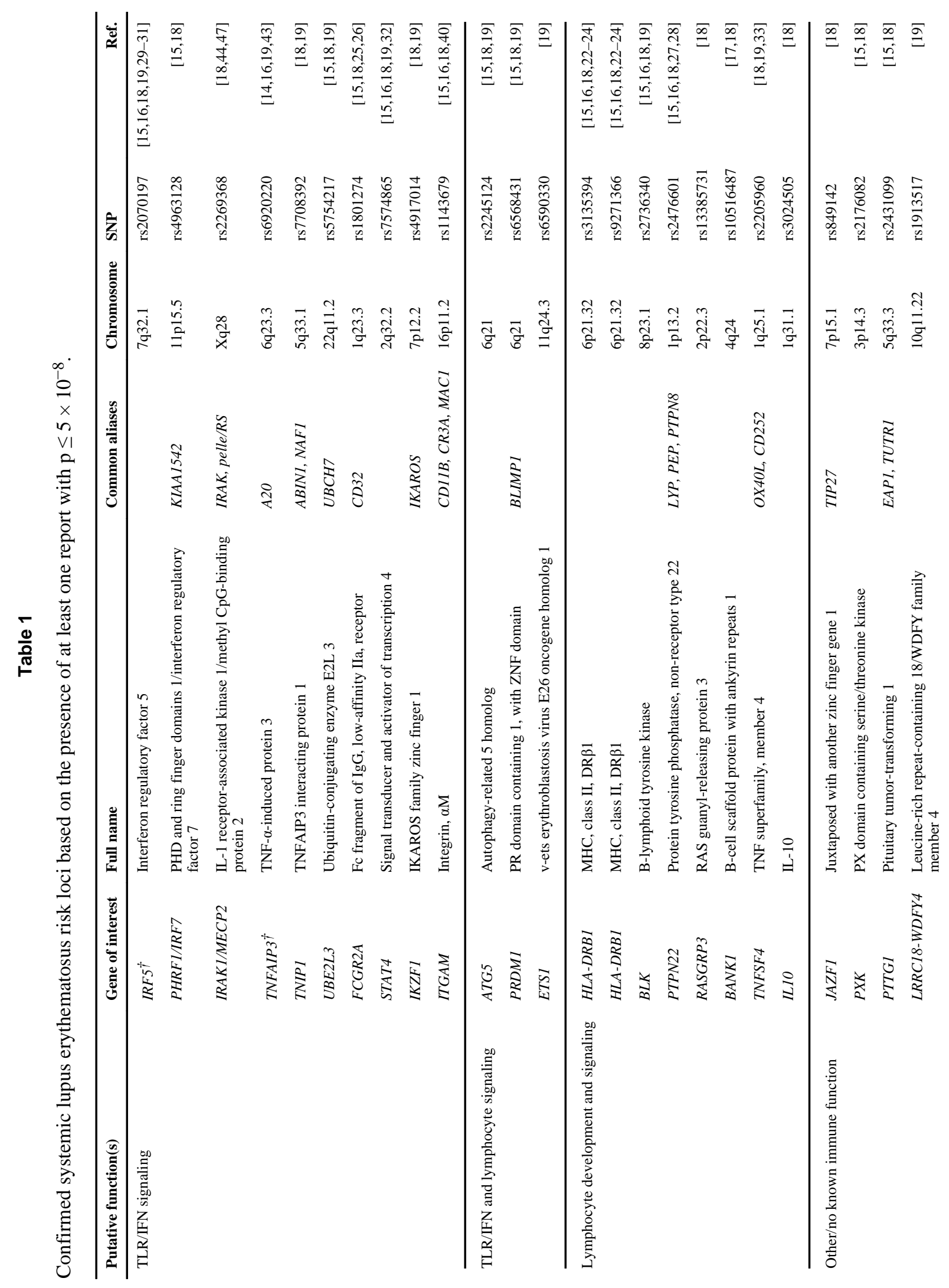

Expert Rev Clin Immunol. Author manuscript; available in PMC 2011 March 1. 


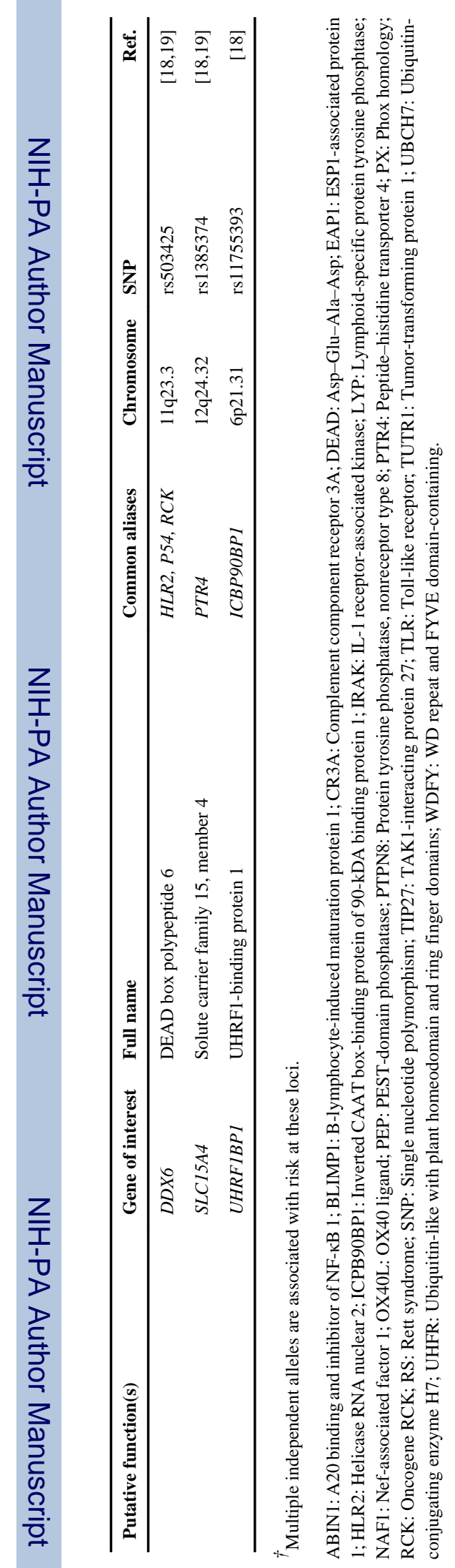

Expert Rev Clin Immunol. Author manuscript; available in PMC 2011 March 1. 


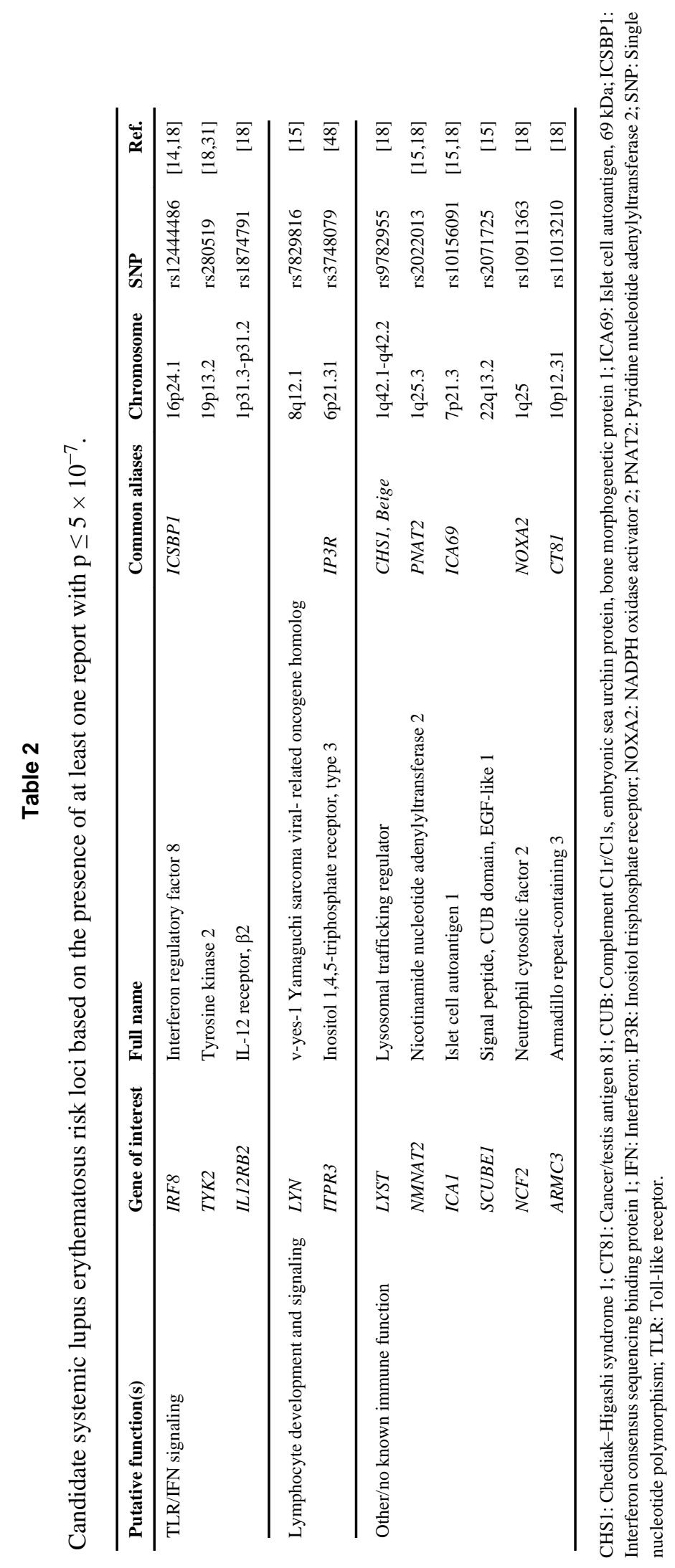




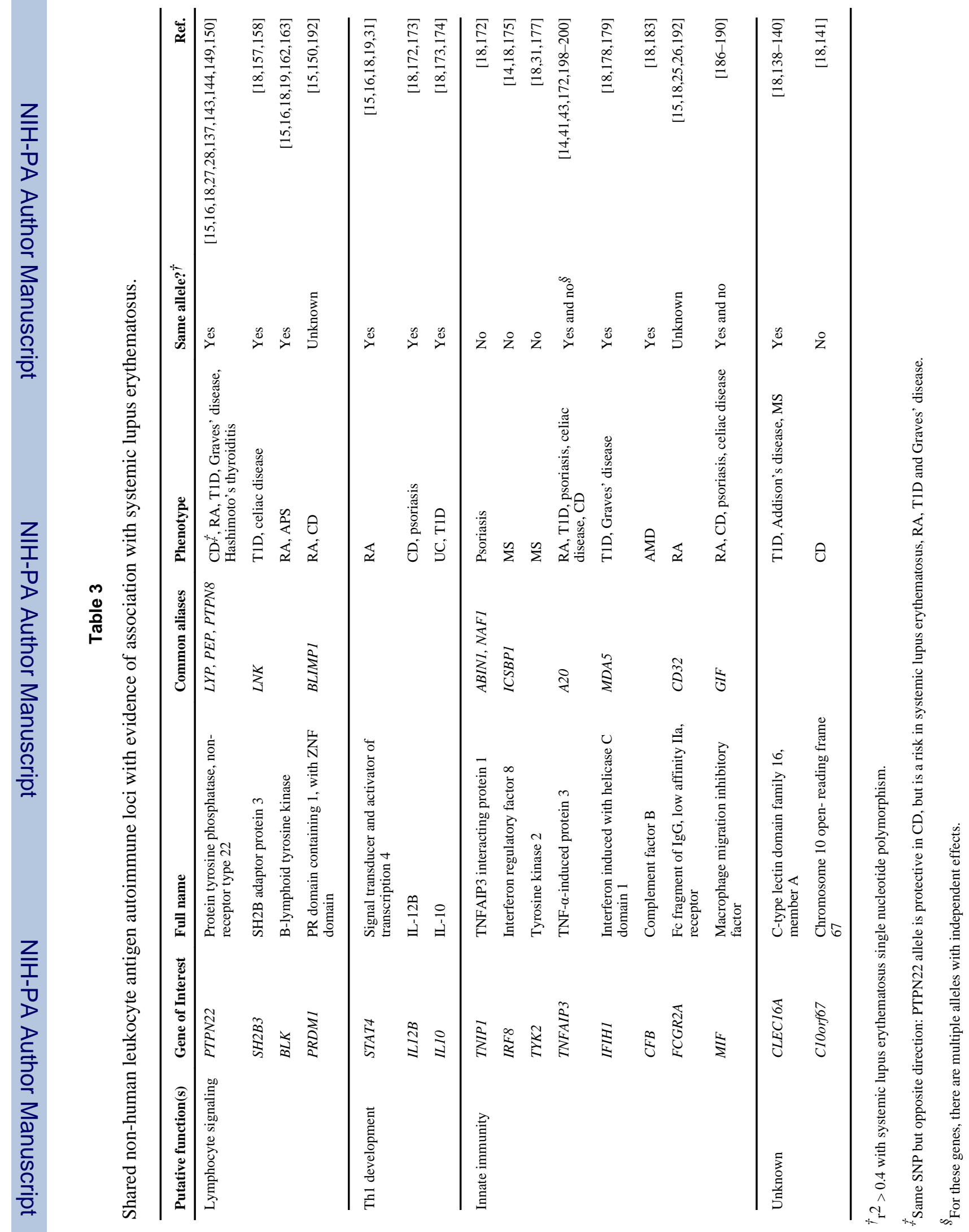

Expert Rev Clin Immunol. Author manuscript; available in PMC 2011 March 1. 


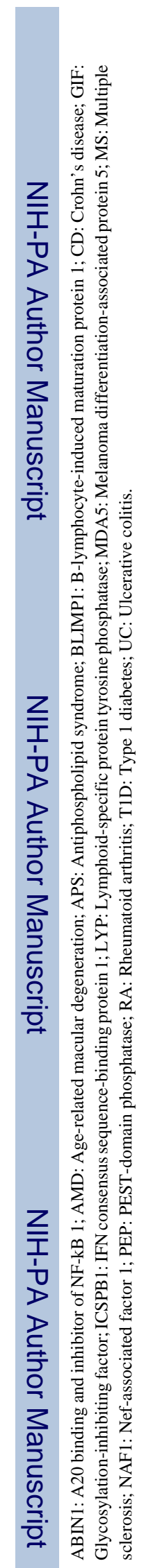

Expert Rev Clin Immunol. Author manuscript; available in PMC 2011 March 1. 